\title{
The MAMs Structure and Its Role in Cell Death
}

\author{
Nan Wang ${ }^{1}$, Chong Wang ${ }^{1}$, Hongyang Zhao ${ }^{1}$, Yichun He ${ }^{1}$, Beiwu Lan ${ }^{1}$, Liankun Sun ${ }^{2, *}$ and Yufei Gao ${ }^{1, *}$ \\ 1 China Japan Union Hospital, Jilin University, Changchun 130031, China; wnan18@mails.jlu.edu.cn (N.W.); \\ chongwang19@mails.jlu.edu.cn (C.W.); zhaohy18@mails.jlu.edu.cn (H.Z.); heyc17@mails.jlu.edu.cn (Y.H.); \\ lanbw20@mails.jlu.edu.cn (B.L.) \\ 2 Key Laboratory of Pathobiology, Ministry of Education, Department of Pathophysiology, \\ College of Basic Medical Sciences, Jilin University, Changchun 130012, China \\ * Correspondence: sunlk@jlu.edu.cn (L.S.); gaoyf@jlu.edu.cn (Y.G.)
}

Citation: Wang, N.; Wang, C.; Zhao, H.; He, Y.; Lan, B.; Sun, L.; Gao, Y. The MAMs Structure and Its Role in Cell Death. Cells 2021, 10, 657. https:// doi.org/10.3390/cells10030657

Academic Editors: Mounia Chami and Stephen Yarwood

Received: 15 January 2021

Accepted: 11 March 2021

Published: 16 March 2021

Publisher's Note: MDPI stays neutral with regard to jurisdictional claims in published maps and institutional affiliations.

\begin{abstract}
The maintenance of cellular homeostasis involves the participation of multiple organelles. These organelles are associated in space and time, and either cooperate or antagonize each other with regards to cell function. Crosstalk between organelles has become a significant topic in research over recent decades. We believe that signal transduction between organelles, especially the endoplasmic reticulum (ER) and mitochondria, is a factor that can influence the cell fate. As the cellular center for protein folding and modification, the endoplasmic reticulum can influence a range of physiological processes by regulating the quantity and quality of proteins. Mitochondria, as the cellular "energy factory," are also involved in cell death processes. Some researchers regard the ER as the sensor of cellular stress and the mitochondria as an important actuator of the stress response. The scientific community now believe that bidirectional communication between the ER and the mitochondria can influence cell death. Recent studies revealed that the death signals can shuttle between the two organelles. Mitochondria-associated membranes (MAMs) play a vital role in the complex crosstalk between the ER and mitochondria. MAMs are known to play an important role in lipid synthesis, the regulation of $\mathrm{Ca}^{2+}$ homeostasis, the coordination of ER-mitochondrial function, and the transduction of death signals between the ER and the mitochondria. Clarifying the structure and function of MAMs will provide new concepts for studying the pathological mechanisms associated with neurodegenerative diseases, aging, and cancers. Here, we review the recent studies of the structure and function of MAMs and its roles involved in cell death, especially in apoptosis.
\end{abstract}

Keywords: endoplasmic reticulum; mitochondria; MAMs; $\mathrm{Ca}^{2+}$; apoptosis

\section{Introduction}

Apoptosis is a programmed form of cell death and can occur via three main pathways. The first pathway is the intrinsic apoptosis pathway; initiated by a range of factors, including the effects of growth factors or hormones, radiation, or cytotoxins [1]. This process involves the enhancement of pro-apoptotic signals and the weakening of anti-apoptotic signals. An imbalance in the regulation of apoptosis ultimately leads to changes in the permeability of the mitochondrial outer membrane and the release of pro-apoptotic substances from the mitochondria. These pro-apoptotic substances promote apoptosis by activating the apoptotic executive protein caspase-9, inhibiting IAPs or via the direct cleavage of DNA [2-7]. The second pathway is the extrinsic apoptosis pathway in which apoptosis is activated by the binding of specific ligands such as FasL to transmembrane receptors which contain "death domain" such as FasR. Activated death receptors then recruit adaptor proteins in the cytoplasm to assemble an apoptosis-inducing signal complex, which then activates caspase- 8 to initiate apoptosis [8]. Caspase- 8 can also cleave Bid to initiate the intrinsic apoptotic pathway, which plays an important role in the process of apoptotic signal amplification $[9,10]$. The third pathway is the perforin/granzyme pathway in which cytotoxic T cells or NK cells induce target cell apoptosis by secreting granules containing perforin or granzymes [11]. 
Moreover, the Bcl 2 family plays a vital role in cell apoptosis. The Bcl2 family consists of 25 members, and they can be divided into pro-apoptotic proteins (Bax, Bak, etc.) and anti-apoptotic proteins (Bcl2, Bcl-XL, Mcl-1, etc.) according to their different functions. Furthermore, pro-apoptotic proteins can be divided into pro-apoptotic proteins with multiple domains and BH3-only proteins, and BH3-only proteins also can be divided into "activator" (Bim, tBid, etc.) and "sensitizer" (Bad, Bik, etc.) based on their specific mechanism of action [12]. The activated pro-apoptotic members can assemble on the outer mitochondrial membrane and change the permeability of the outer mitochondrial membrane, and promote the release of cytochrome c, AIF, Smac/Diablo and other apoptosis-inducing factors from the mitochondria [13]. Anti-apoptotic members mainly antagonize the effects of pro-apoptotic ones through protein-protein interactions to maintain the integrity of the mitochondrial outer membrane. The "activator" BH3-only members can directly activate the pro-apoptotic proteins and promote the occurrence of apoptosis, while the "sensitizer" BH3-only members can interact with the anti-apoptotic in a protein-protein interaction way to relieve the effect of the pro-apoptotic proteins [14].

As it is mentioned above, the mitochondria play a central role in the cell apoptosis, and the crosstalk between mitochondria and other organelles may impact the apoptosis process. Recent studies revealed that the communication between ER and mitochondria can influence the cell apoptosis, thus affecting the cell fate.

The ER is a key organelle that plays a crucial role in $\mathrm{Ca}^{2+}$ storage, lipid synthesis, protein folding, and assembly [15-18]. Mitochondria are the "energy factories" of eukaryotic cells, and provide energy to drive the physiological processes of cells; they also play a key role in the process of apoptosis [19-21]. The ER and mitochondria are independent of each other but are also closely associated in structure and function. The first spatial connection between the ER and the mitochondria was reported in the 1950s following a study of hepatocytes by transmission electron microscopy [22,23]. In 2006, an electron tomography study further confirmed the complex relationship between the ER and the mitochondria [24]. It is now believed that the mitochondrial surface juxtaposed to the ER in mammalian cells is up to $5-20 \%$ due to different cell types $[25,26]$. Based on this close structural connection, the ER is able to respond to a variety of stress stimuli and can transmit these stress signals to the mitochondria $[27,28]$, thereby initiating the mitochondrial stress response. Similarly, the mitochondria can transmit signals to the ER, thus ensuring the efficient execution of compensatory responses or cell death events. Due to the special function of these precise structural associations, this biological system is usually investigated as a relatively independent sub-organelle structure referred to as a "mitochondrial-related membrane structure."

\section{The Structural Characteristics of MAMs}

The structure of MAMs does not remain constant; rather, the structure of MAMs changes dynamically in response to the cell status. The width of the gap between the ER and the outer mitochondrial membrane varies from 10 to $100 \mathrm{~nm}[29,30]$; the width of this gap is usually $10-15 \mathrm{~nm}$ at the smooth endoplasmic reticulum and $20-30 \mathrm{~nm}$ at the rough endoplasmic reticulum; these spatial differences may be related to the presence of ribosomes [7,31]. Different proteomic analysis of the structure of MAMs has revealed 991 [32] and 1212 [33] different proteins in MAMs [34]. Mass spectrometry analysis divided these constituent proteins into three categories: Proteins that are specifically present in MAMs; proteins that exist simultaneously in MAMs and other organelle structures; and proteins that only exist temporarily in MAMs [33]. These proteins are involved in a wide range of processes, such as structural maintenance, lipid synthesis, the regulation of $\mathrm{Ca}^{2+}$ homeostasis, mitochondrial dynamics, and apoptosis.

\section{The Structure Maintenance of MAMs}

There are thousands of proteins in MAMs; the roles of these proteins are known to vary widely. Some of these proteins play a tethering role in the maintenance of MAMs [31]. 
According to our understanding, tethering proteins should exhibit certain characteristics. For example, tethering proteins could be (1) proteins or protein complexes that directly participate in the physical connection between the ER and the mitochondria, or (2) interfering proteins or protein complexes that can directly cause changes in the width of gap, the area of contact, or the number of contact sites between the ER and the mitochondria. These proteins and protein complexes are introduced below (Figure 1).

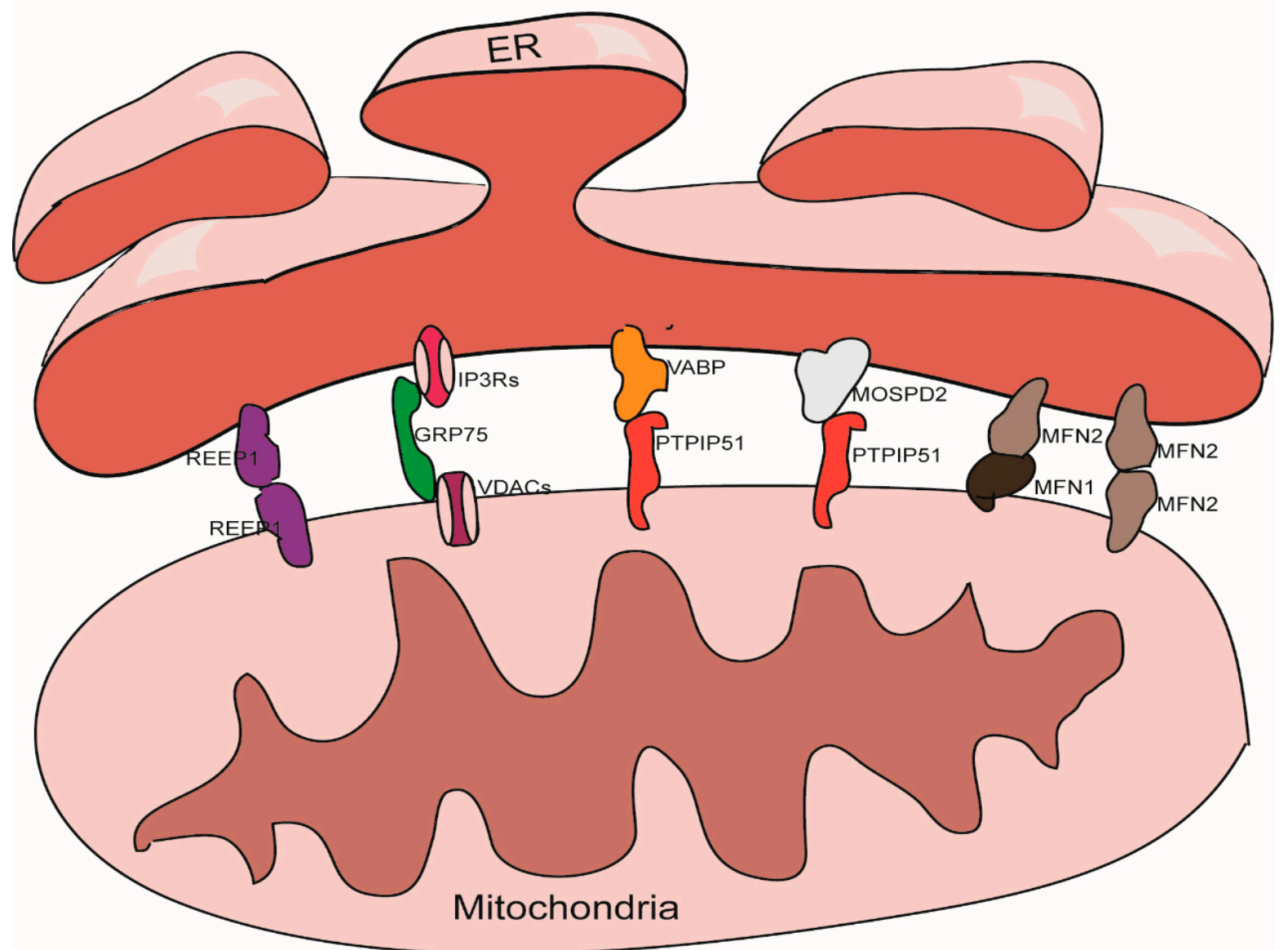

Figure 1. Tethering proteins that participate in the mitochondria-associated membranes (MAMs) structure maintenance.

\subsection{The IP3Rs-Grp75-VDACs Complex}

IP3Rs are important $\mathrm{Ca}^{2+}$ outflow channels on the surface of the ER and mediate the release of $\mathrm{Ca}^{2+}$ from the cavity of the ER to the cytoplasm [35,36]. VDACs are ions channel located on the outer membrane of the mitochondria; these mediate the movement of a variety of ions and metabolites in and out of mitochondria, and participate in a range of cellular activities, including apoptosis, metabolism, and the regulation of $\mathrm{Ca}^{2+}$ [37]. IP3Rs and VDACs are connected by Grp75 to maintain the structure of MAMs [38]. The overexpression of VDACs is known to enhance the connection between the ER and the mitochondria and thus improve $\mathrm{Ca}^{2+}$ flux from the ER to the mitochondria [39]; while silencing VDAC1 exhibits a reduction in the connection between Grp75 and IP3R1 indicating a reduction of ER-mitochondria interactions [40]. Cells overexpressing Grp75 showed higher number of IP3R1-VDAC1 interaction sites [41]. Silencing IP3R1 or Grp75 can also reduce the connection between VDAC1 and Grp75 or IP3R1 [42].

\subsection{The VAPB-PTPIP51 Complex}

VAPB is located in the membrane of the ER and participates to the activation of the IRE1/XBP1 axis in the ER unfolded protein response [43,44]. VAPB can form a complex 
with the outer mitochondrial membrane protein PTPIP51 and help to maintain the structure of MAMs. A mutant form of VAPB, VAPBP56S, exhibits a stronger affinity for PTPIP51, thereby promoting the transfer of $\mathrm{Ca}^{2+}$ from the ER to the mitochondria; knocking out either of these two genes can reduce the transfer of $\mathrm{Ca}^{2+}$ signals [45]. Other studies have shown that knocking down either of these two proteins will reduce the level of contacts between the ER and the mitochondria [46,47].

\subsection{The Mfn1/Mfn2 Complex}

In addition to being located in the outer mitochondria membrane and participating to the mitochondrial fusion [48], Mfn2 can also localize on the surface of the ER. Mfn2 participates in the structural maintenance of MAMs by forming homodimers or heterodimers with Mfn1/2 on the outer membrane of the mitochondria. The function of the Mfn1/Mfn2 complex with regards to maintaining the structure of the MAMs was first discovered in 2008 [49]; this role has also been confirmed by several other studies [50,51]. However, some studies have yielded contradictory results [52,53], it is now well established that Mfn2 plays a role in the endoplasmic reticulum stress (ERS) response; the ERS induced by knockdown of Mfn2 can tighten the association between the ER and the mitochondria [54].

\subsection{The MOSPD2-PTPIP51 Complex}

MOSPD2, another member of VAP family, a protein that locates on the surface of the ER membrane, plays a role in connecting the ER with other membrane structures. It can also bind with proteins containing a small VAP-interacting motif, named FFAT [two phenylalanines (FF) in an acidic track (AT)] via an MSP (Major Sperm Protein domain), such as PTPIP51 on the outer membrane of the mitochondria [55].

\subsection{REEP1}

REEP1 is a protein that is located in the outer membrane of the ER and the mitochondria. REEP1 helps regulate the morphology of the ER. Studies have shown that REEP1 directly connects the ER and the mitochondria through oligomerization and participates in forming the structure of MAMs. In addition, through bending ER membranes, REEP1 makes it topologically possible for the ER to wrap around the mitochondria, which helps to form MAMs [56].

\subsection{Other Proteins Involved in MAMs Maintance}

In addition to these tethering proteins, there are some proteins that do not directly participate in the structural maintenance of MAMs. However, these proteins do affect the structure of MAMs via protein-protein interactions (Table 1). In addition to being present in the cytoplasm, $\alpha$-Synuclein can also be incorporated in MAMs [57]. $\alpha$-Synuclein can promote the $\mathrm{Ca}^{2+}$ transfer from ER to mitochondria by increasing the ER and mitochondria contacts; and further study showed that the C-terminal of $\alpha$-Synuclein is essential to tighten the contacts [58]. Some studies revealed that the $\alpha$-Synuclein existing in MAMs results in the dis-regulation of $\mathrm{Ca}^{2+}$ and lipid metabolism, which promotes substantia nigra pars compacta neurons to die, leading to the progression of PD [59]. In addition to playing an anti-apoptotic role in cells and participating in mitochondrial dynamics, DJ-1 can still exist in the MAMs, thus enhancing the connection between the ER and the mitochondria and the crosstalk between the two organelles; this effect may be related to P53 to some extent (an antagonistic relationship) [60]. Existing studies suggest that DJ-1 can bind directly to the IP3R-Grp75-VDAC complex and affect its stability. The knockout of DJ-1 resulted in the aggregation of IP3R3 in MAMs and a reduction in the formation of the IP3Rs-Grp75VDACs complex; it is possible that this is related to the pathophysiological process of obesity [61]. Although the precise mechanism remains obscure, it has been ascertained that DJ-1 can affect the structural stability of MAMs. This also implies that MAMs may play a role in the pathogenesis of Parkinson's syndrome. TDP-43 and FUS are proteins that are related to ALS/FTD and can activate GSK-3b by down-regulating the phosphorylation 
levels of serine 9 by GSK-3b. Once activated, GSK-3b can reduce the connections between VABP and PTPIP51, thereby detaching the ER from the mitochondria [47,62]. PDK4 can directly interact with the IP3Rs-Grp75-VDACs complex in MAMs and may promote the formation of this complex by regulating phosphorylation, thus increasing the area of contacts between the ER and the mitochondria [42]. In addition to participating in the post-transcriptional modification of proteins, TG2 can also be incorporated in MAMs and act directly on Grp75 to increase the number of ER-mitochondrial contacts and thus participate in the structural maintenance of MAMs [63]. The precise function of TpMs (a type of keratin binding protein that is partly located in the mitochondria) remains unclear although data indicates that this protein can negatively regulate the ER-mitochondria connections in a Mfn2-dependent manner [64]. It is generally believed that CypD, a protein located in the mitochondrial matrix, can also be incorporated in MAMs, and directly act with the IP3Rs-Grp75-VDACs complex to regulate the stability of this complex. Inhibiting the function of CypD can down-regulate the binding of Grp75 with IP3Rs and VDACs, affecting the transfer of $\mathrm{Ca}^{2+}$ between the two organelles [65]. FUNDC1 is known for maintaining the stability of IP3R2 in MAMs by direct binding, and it enhances the level of contacts and the communication of $\mathrm{Ca}^{2+}$ between the ER and the mitochondria [66]. Presenilin-2 can also promote the connection and the transfer of $\mathrm{Ca}^{2+}$ signals between the ER and the mitochondria in the presence of Mfn-2; these findings were confirmed by overexpression and knockdown experiments, which suggested that presenilin- 2 works with the Mfn1/Mfn2 complex [67]. FATE1 can reduce the level of contacts between the ER and the mitochondria and downregulate the transfer of $\mathrm{Ca}^{2+}$ with an impaired sensitivity to $\mathrm{Ca}^{2+}$-related apoptosis [68]. In addition to participating in the morphological regulation of ER, NogoB can increase the gap width of MAMs and affect their function [69]. PERK, which plays an important role in ERS, can increase the level of connectivity between the $\mathrm{ER}$ and the mitochondria by interacting with Mfn2, and thus promote the transduction of ERS signals to the mitochondria [70,71]. Although these proteins are not considered to be directly involved in maintaining the structure of MAMs, they still attract research attention due to their specific regulatory effects on the structure of MAMs and their involvement in the pathological processes underlying many neurodegenerative diseases.

\section{MAMs and Cell Death}

MAMs plays a crucial role in cell homeostasis as mentioned above, besides, recent studies revealed that MAMs can also influence the cell death events. The death signals in MAMs attend in multiple forms, such as the transfer of $\mathrm{Ca}^{2+}$ from the ER to the mitochondria, regulation of protein-protein interactions, the translocation of molecules or the control of lipid metabolism. These processes are described in detail in the following sections (Figure 2). 


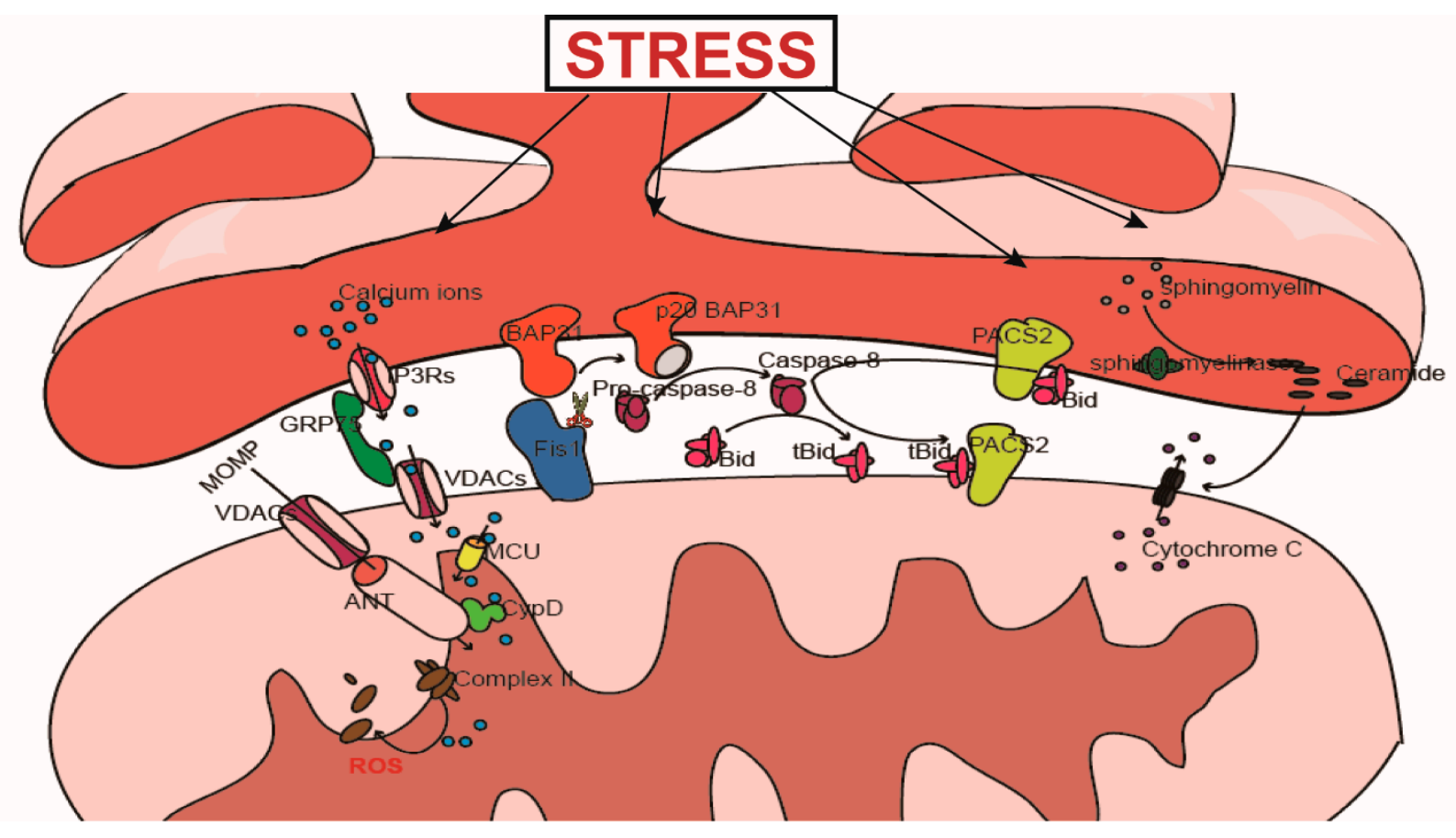

Figure 2. Under stress conditions, endoplasmic reticulum (ER) can act as a sensor and respond immediately. Meanwhile, if the stress intensity exceeds the adaptability of the ER, it will transmit death signals to mitochondria to initiate death events. The transduction can go through some pathways as follows: 1 .ER perfuse $\mathrm{Ca}^{2+}$ into mitochondria and massive $\mathrm{Ca}^{2+}$ in mitochondria works as a death signal initiating cell death; 2. translocation of PACS1 from ER to mitochondria, which is along with the activation and translocation bid; 3 . ceramide synthesis and accumulation causing the mitochondrial outer membrane permeabilization (MOMP), which results in the release of cytochrome c or other pro-apoptotic substances in inter membranes space. Also, as a molecule downstream of mitochondrial apoptosis, Fis1 can transmit apoptosis signal back to ER by cleaving BAP31. The ER-mitochondria-ER amplification loop of apoptotic signals can help to coordinate the death events between the two organelles.

\section{1. $\mathrm{Ca}^{2+}$-Mediated Signal Transduction and Cell Death}

\subsubsection{The Physiological Role of $\mathrm{Ca}^{2+}$}

$\mathrm{Ca}^{2+}$ is an important vector for crosstalk between the ER and the mitochondria [72]. The ER, as the most important cellular reservoir of $\mathrm{Ca}^{2+}$, maintains proper $\mathrm{Ca}^{2+}$ level by $\mathrm{Ca}^{2+}$ pumps SERCAs [73]. SERCAs have varied isoforms, among which the ubiquitous SERCA2b shows the highest affinity to $\mathrm{Ca}^{2+}$ uptake from the cytoplasm [26]. ER releases $\mathrm{Ca}^{2+}$ into the cytoplasm via RyRs and IP3Rs. The IP3Rs are more ubiquitously expressed while RyRs mostly expressed in skeletal muscle, heart and brain [74]. IP3Rs have three isoforms and all of them can be activated by IP3, $\mathrm{Ca}^{2+}, \mathrm{Ca}^{2+}$-binding proteins, ATP, thiol modification and phosphorylation [75]. Although cytoplasmic $\mathrm{Ca}^{2+}$ can almost pass freely through the VDACs of the outer mitochondrial membrane, the MCU located in the inner mitochondrial membrane has a weak affinity for $\mathrm{Ca}^{2+}(\mathrm{Kd} 15-20 \mu \mathrm{M})$, meanwhile, the concentration of $\mathrm{Ca}^{2+}$ in the cytoplasm fluctuates between 50 and $100 \mathrm{nM}[16,76]$. The mechanism responsible for the uptake of cytoplasmic $\mathrm{Ca}^{2+}$ by the mitochondria has been debated by the academic community for many years. Many models, such as $\mathrm{Ca}^{2+}$ microdomain hypothesis, was proposed to explain the $\mathrm{Ca}^{2+}$ uptake mechanism $[25,77,78]$. However, with the deepen understand of the MAMs, especially the IP3Rs-Grp75-VDACs complex, advancement was made with this respect. When the ER calcium channels are opened, a hotspot of calcium will be produced in microdomain between the ER and the mitochondria; this makes it possible for the mitochondria to uptake $\mathrm{Ca}^{2+}$ [16]. In this process, the IP3Rs-Grp75-VDACs complex plays a crucial role, though there exist some proteins, such as the MiCU family, MCUR1 and SLC25A23, play regulatory role in the 
work of $\mathrm{MCU}$, which may affect the $\mathrm{Ca}^{2+}$ uptake efficiency, and the elegant mechanism can be seen in the review by Belosludtsev KN et al. [79].

The presence of $\mathrm{Ca}^{2+}$ in the mitochondrial matrix can play a variety of roles. First, it can promote the efficiency of the tricarboxylic acid cycle and the electron transport chain (ETC). $\mathrm{Ca}^{2+}$ is known to increase the activities of pyruvate dehydrogenase, ketoglutarate dehydrogenase, and isocitrate dehydrogenase, in the tricarboxylic acid cycle [30] and can directly stimulate ETC-related complexes, thus improving the activity of ATP synthase and promoting the production of ATP $[80,81]$. It has also been reported that $\mathrm{Ca}^{2+}$ can affect metabolism by regulating the activity of glucose transporters [82]. Second, longterm and high-level $\mathrm{Ca}^{2+}$ overload can induce cell death. $\mathrm{Ca}^{2+}$ can induce the opening of MPTP, which may result in necrosis [83], or the resultant mitochondrial swelling and outer membrane rupture in limited MPT (the open of MPTP does not involve the entire mitochondrial network, and it may appear as "flickering" mode in a small portion of mitochondria) can result in the release of pro-apoptotic substances such as cytochrome $\mathrm{c}$ and AIF [84-86]. An excessive concentration of $\mathrm{Ca} 2+$ in the mitochondria can bind to cardiolipin in the inner membrane of mitochondria to promote the disintegration of respiratory chain complex II, thus leading to the release of multiple subunits; this also induces the production of large amounts of ROS, thereby inducing apoptosis [87]. Like a double-edged sword, $\mathrm{Ca}^{2+}$ can both promote metabolism and induce cell apoptosis. The flux of $\mathrm{Ca}^{2+}$ determines which cellular events occur, thus highlighting the importance of MAMs structure to cells.

\subsubsection{The Regulatory Effect of MAMs on $\mathrm{Ca}^{2+}$ Transfer}

The IP3Rs-Grp75-VDACs complex is the basis for $\mathrm{Ca}^{2+}$ regulation in MAMs; the importance of this complex is the maintenance of physical contacts between the ER and the mitochondria, while enables the combination of IP3Rs and VDACs to overcome the MCU's low affinity for $\mathrm{Ca}^{2+}$, thus increasing the sensitivity and efficiency of $\mathrm{Ca}^{2+}$ delivery. Also, another MAMs-presented protein, SERCAs, is fundamental to regulate the $\mathrm{Ca}^{2+}$ level in $\mathrm{ER}$, whose activity can affect the $\mathrm{Ca}^{2+}$ flux pass through MAMs.

\section{The IP3Rs-Grp75-VDACs Complex}

A variety of proteins regulate the transfer of $\mathrm{Ca}^{2+}$ between the ER and the mitochondria by interacting with the IP3Rs-Grp75-VDACs complex. mTORC2 can accumulate in MAMs under the stimulation of various growth factors; and mTORC2 in MAMs can phosphorylate Akt and elevate its activity. Moreover, activated Akt can elevate the phosphorylation level of IP3Rs, thus reducing the release of $\mathrm{Ca}^{2+}$ in the ER and antagonizing cell apoptosis [88-92]. Antagonistically, PML can affect the phosphorylation level and activity of Akt by elevating the activity of phosphatase PP2A to regulate the function of IP3Rs [93]. As an important protein encoded by tumor suppressor genes, PTEN can counteract Akt and promote $\mathrm{Ca}^{2+}$ transfer from the ER to the mitochondria, thus increasing the sensitivity of cells to apoptotic stimuli [94].

As an important player that can affect cell fate, the functional role of the Bcl2 family may depend on the interaction between Bcl2s and MAMs, at least to a certain extent. Bcl2 and Bcl-xl can directly bind to the central regulatory domain of IP3Rs or indirectly affect the phosphorylation level of IP3Rs to inhibit the function of IP3Rs; they can also interact with VDAC1 to reduce the uptake of $\mathrm{Ca}^{2+}$ by the mitochondria $[13,95,96]$. In addition to directly inhibiting the activity of IP3Rs [97], Mcl-1, which is also a member of Bcl2 family, can enhance cellular metabolism by interacting with VDACs to promote the transfer of $\mathrm{Ca}^{2+}$ [98]. Bok, a pro-apoptotic member of the Bcl2 family, can interact with IP3Rs and change the ratio of IP3R1 and IP3R2 by cleavage; this process is carried out by caspase- 3 and results in an increased $\mathrm{Ca}^{2+}$ transfer and increased cellular sensitivity to apoptosis $[99,100]$. More elegant details in this field can be seen in the review by Lewis A, et al. [101].

Sig- $1 \mathrm{R}$ plays a role in the pathogenesis of a variety of neurodegenerative diseases, including Alzheimer's disease, Parkinson's syndrome, and the lateral sclerosis of associated 
with muscular dystrophy [102]. Sig-1R is an important component of MAMs. A previous study showed that Sig-1R can be separated from Bip and combines with IP3Rs under conditions of mitochondrial stress, thus reducing the degradation of IP3Rs and promoting the transfer of $\mathrm{Ca}^{2+}$ to the mitochondria [103]. Caveolin-1 is known for that it helps to order the lipid bilayers organization [104]; moreover, it can directly interact with IP3Rs to promote the release of $\mathrm{Ca}^{2+}$ [105], while Ras can affect the subcellular distribution of Caveolin-1, thereby reducing the transfer of $\mathrm{Ca}^{2+}$ [106]. During the process of apoptosis, the tumor suppressor BRCA1 can be recruited to the surface of the ER in an IP3Rs-dependent manner and bind directly to IP3R1 to increase its sensitivity to IP3 and promote the transfer of $\mathrm{Ca}^{2+}$ to the mitochondria [107]. WFS1, NCS1, and IP3Rs, can form a complex to increase the connectivity between the ER and the mitochondria by enhancing $\mathrm{Ca}^{2+}$ transfer [108]. Research has shown that the mutation of WFS1 is responsible for a variety of abnormalities in the neurological and endocrine systems [109]. Tespa1 can be incorporated in MAMs and participate in the regulation of $\mathrm{Ca}^{2+}$ transfer by way of forming a complex with IP3Rs and Grp75. The knockdown of Tespa1 can down-regulate the level of $\mathrm{Ca}^{2+}$ in the mitochondria and cytoplasm $[110,111]$. ERO1 $\alpha$ is also known to increase the activity of IP3Rs and promote apoptosis [112].

\section{SERCAs}

As the only channel responsible for the uptake of $\mathrm{Ca}^{2+}$ in the ER so far, SERCAs can also aggregate in MAMs. Furthermore, a variety of proteins in MAMs can regulate the function of SERCAs and affect the transfer of calcium signals. When incorporated in MAMs, P53 can change the redox state of SERCAs and promote its functional activity, thereby elevating the level of $\mathrm{Ca}^{2+}$ in the ER; this increases the flux of $\mathrm{Ca}^{2+}$ to the mitochondria, and promotes the occurrence of apoptosis $[113,114]$. TMX1 can negatively regulate the function of SERCA2b, and tumor cells with low expression levels of TMX1 exhibit higher levels of $\mathrm{Ca}^{2+}$ in the ER $[115,116]$. The anti-apoptotic protein Bcl-2 can directly bind to SERCAs to change its conformation, thereby down-regulating its functional activity and inhibiting the enrichment process of $\mathrm{Ca}^{2+}$ in the ER [117]. SEPN1 and ERO1 $\alpha$ antagonize each other and work by regulating the redox state of SERCA2. SEPN1 can down-regulate the cysteine oxidation level of SERCA2 to maintain the stability of SERCA2 function [118].

In addition, 25 transcriptional variants of SERCA1 were detected in normal liver cells, among which 8 clones were found to be characterized by exon 11 splicing, named S1Ts. Further study revealed that S1Ts are expressed in different human tissues, such as adult pancreas, liver, kidney, lung, and placenta and fetal kidney, liver, brain, thymus [119]. S1Ts, which are localized in MAMs, can be induced by ER stress through PERK-eIF2 $\alpha$-ATF4 pathway and whose induction triggers $\mathrm{Ca}^{2+}$ leak from ER by forming homodimers in the ER membrane, which promotes the transfer of $\mathrm{Ca}^{2+}$ to mitochondria $[119,120]$.

\section{MCU}

Although MCU and its regulatory proteins play crucial role in the uptake of $\mathrm{Ca}^{2+}$ by the mitochondria [79], there is no report showing specific accumulation of MCU at MAMs structure. However, MAMs can still influence the efficiency of MCU in $\mathrm{Ca}^{2+}$ uptake. Since the transport of $\mathrm{Ca}^{2+}$ by MCU is highly dependent on the "hot spot" effect of ER Ca ${ }^{2+}$ release, the MAMs proteins that can influence the spatial connection between the ER and the mitochondria (as detailed above) may influence the $\mathrm{Ca}^{2+}$ delivery efficiency by MCU indirectly (Table 1). 
Table 1. Proteins that play roles in MAMs structure and function regulation.

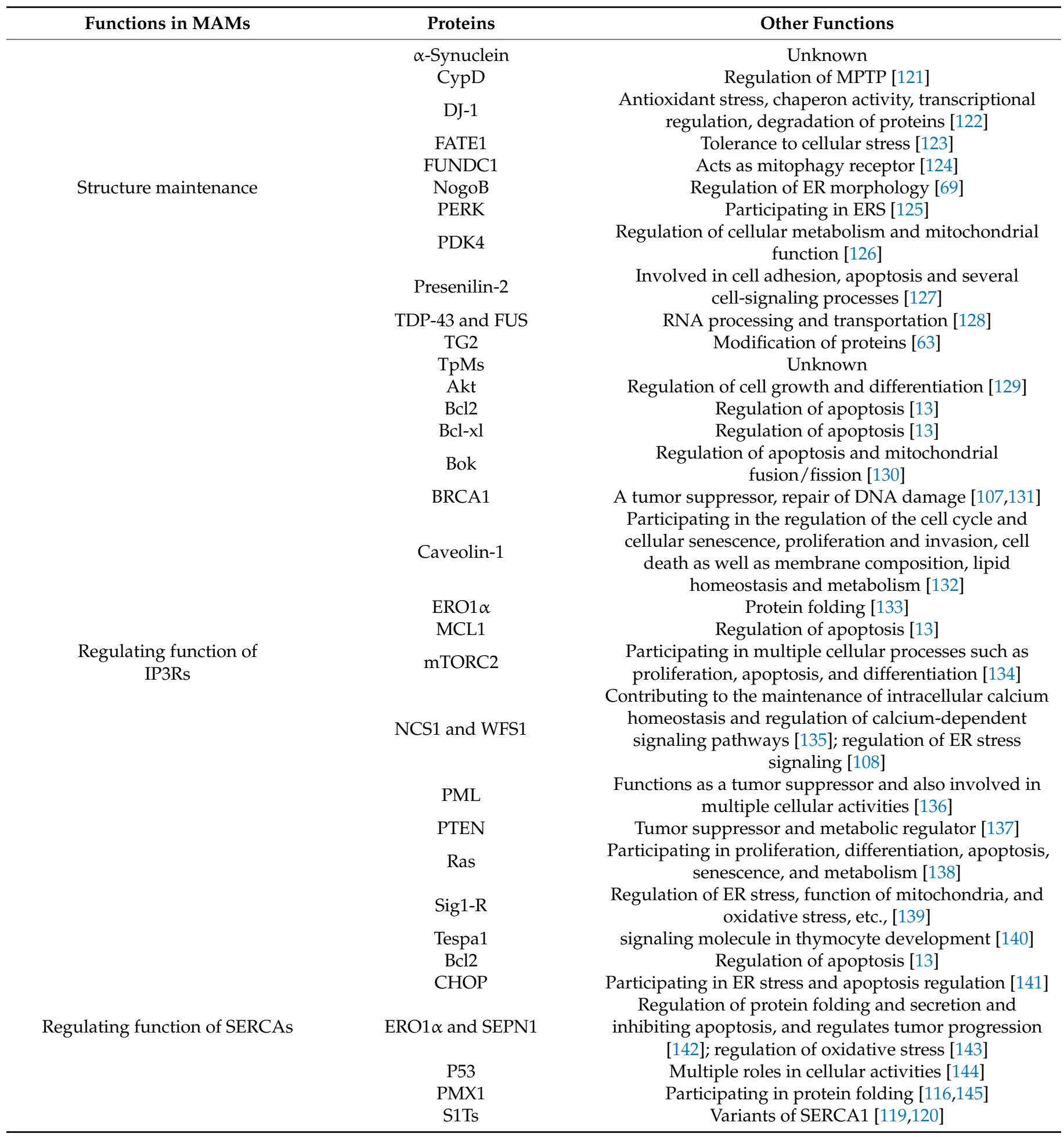

\subsection{PACS2 Participates in the Transduction of Apoptosis Signals from the ER to the Mitochondria}

PACS2 is a sorting protein located in the ER membrane which participates in the regulation of ER homeostasis, lipid synthesis, and the structural connection between the ER and the mitochondria. In addition, PACS2 mediates the process of apoptotic signal transduction from the ER to the mitochondria. High levels of ERS can cause translocation of the full-length Bid-bound PACS2 from the ER to the mitochondria; Bid is then cleaved on the surface of the mitochondria by caspase-8. Later, Bid interacts with Bax/Bak to promote 
permeability of the outer membrane of the mitochondria and the release of cytochrome c, thus initiating apoptosis [21].

\subsection{The Role of LIPID Metabolism in the Transduction of Apoptosis Signals}

MAMs plays a central role in lipid metabolism. A variety of lipids are synthesized in MAMs; some enzymes involved in the synthesis of triglyceride, ceramide, and sterol (fatty acid CoA ligase (ACS) 1/4) [146], acyl-coenzyme A: cholesterol acyltransferase-1 (ACAT1/SOAT1) [147] are known to exist only in MAMs [148]. Several lipid metabolites can affect cell fate. Of these, ceramide is the most typical. Under normal circumstances, ceramide is synthesized by the ceramide synthase pathway. However, under stress conditions (e.g., heat shock, TNF- $\alpha$, Fas, chemotherapeutics, toxins, radiation and other factors) ceramide can be synthesized rapidly from sphingomyelin in the nerve sheath phospholipase [149]. The accumulation of ceramide can not only regulate and interact (directly or indirectly) with a variety of molecules involved in the transduction of apoptotic signals transduction, such as protein phosphatase $1 \mathrm{~A} / 2 \mathrm{~A}$, protein kinase $\mathrm{C}$, and NF- $\mathrm{kB}$, ras [150-154], a significant accumulation of ceramide can result in the formation of pores on the outer mitochondrial membrane, induce the release of pro-apoptotic substances, such as cytochrome c, in the intermembrane space of mitochondria $[155,156]$, and transfer stress signals from the ER to the mitochondria. Inhibiting the activity of ACS1/4 can reduce the synthesis of ceramide and reduce the occurrence of apoptosis [157].

\subsection{The Fis1-BAP31 Complex Is Involved in the Transduction of Apoptosis Signals \\ 4.4.1. The Relationship between Fis1 and Apoptosis}

As the receptor for Drp1 during mitochondrial fission, Fis1 not only plays an important role in mitochondrial fission, but also participates in the process of apoptosis. First, the downregulation of Fis1 can reduce the release of cytochrome $\mathrm{c}$ in apoptotic cells and can inhibit the translocation of pro-apoptotic Bcl2 family members to the mitochondria [158]. Second, the overexpression of Fis1 can induce cell apoptosis via a Bax/Bak-independent process $[159,160]$. Although many studies have found that mitochondrial fission is often accompanied by the release of mitochondrial apoptosis-related substances, it is currently believed that when considering the relationship between mitochondrial fission and apoptosis, mitochondrial fission is the result of cell apoptosis rather than the cause. The results of multiple time-lapse microscopy experiments have confirmed that the release of cytochrome c from mitochondria when stimulated with apoptosis-inducing drugs occurs earlier than mitochondrial fission, and that the release of cytochrome $\mathrm{c}$ can also occur in both reticulated and tubular mitochondria $[161,162]$. Therefore, Fis1 is involved in the process of apoptosis and plays a specific role that occurs downstream of mitochondrial apoptosis.

4.4.2. Fis1-BAP31 Participates in Apoptosis Signal Transduction from the Mitochondria to the ER

As a participant in the process of apoptosis, Fis1 can connect with BAP31 in MAMs to transmit mitochondrial apoptotic signals to the ER. BAP31 is an important chaperone protein on the ER membrane and is involved in the degradation of misfolded proteins and apoptosis within the ERS pathway. When Fis1 binds to BAP31, it can cleave BAP31 to produce p20 BAP31; as a pro-apoptotic protein, p20 BAP31 can convert procaspase- 8 into an functional form that can truncate Bid and initiate apoptosis [21,163]. The activation of p20 BAP31 can also promote the transfer of $\mathrm{Ca}^{2+}$ from the ER to the mitochondria, thus showing that apoptosis signals can return back to the mitochondria [164,165], thus forming an amplification loop of apoptotic signals between the ER and the mitochondria that can help to coordinate the functions of these two organelles. 


\section{Methods of Detection}

\subsection{Fluorescence Microscopy}

Fluorescence microscopy provides a preliminary solution for studying the structure of MAMs. Some researchers have used the co-localization of markers for the ER and mitochondria to study the connectivity between these two organelles $[49,53]$. However, in confocal fluorescence microscopy, the resolution of the $z$-axis is only $700 \mathrm{~nm}$. Even though the most advanced microscopes can reach $300-400 \mathrm{~nm}$ [166], this is still not sufficient to measure the spatial gaps in MAMs (usually less than $100 \mathrm{~nm}$ ). This means that results obtained via fluorescence microscopy may be questionable, although fluorescence microscopy still has certain advantages. First, fluorescence microscopy can observe living cells, making it possible to study the dynamic structure of MAMs [167]; second, with the application of a variety of fluorescent labels and proteins, the study of MAMs can be more targeted and efficient [38]. Consequently, fluorescence microscopy remains an indispensable method to study MAMs.

\subsection{Transmission Electron Microscopy}

Transmission electron microscopy is an irreplaceable tool for studying the structure of MAMs. The high-resolution imaging of transmission electron microscopy makes it possible to quantify the structure of MAMs [168]. At the same time, three-dimensional reconstruction technology after electron tomography can rebuild the structure of MAMs between the ER and mitochondria, making it possible to study the spatial morphology of MAMs [169-171]. This can provide a new perspective in the study of MAMs besides gap measurement and contact point quantification [144,172]. In addition, the combination of fluorescence microscopy and electron microscopy technology can be highly complementary and allow the study of both structure and function [159].

\subsection{Gradient Centrifugation}

Gradient centrifugation is a classic method for studying MAMs [173]. In combination with methods such as immunoblotting, immunofluorescence, mass spectrometry, and proteomics, the molecular composition of MAMs can be analyzed qualitatively and quantitatively [33]. In this process, gradient centrifugation is an important means to separate the structure of MAMs. However, there are also reports describing the use of biotin to separate and purify the structure and composition of MAMs and thus allow the qualitative and quantitative investigation of the composition of MAMs [174,175].

\subsection{The Functional Evaluation of MAMs}

The functional evaluation of MAMs can indirectly reflect the changes in the level of contact between the ER and the mitochondria. The synthesis of phospholipids and their transportation between the ER and the mitochondria, or the flux of $\mathrm{Ca}^{2+}$ transfer from the ER to the mitochondria, are usually used as indicators to reflect changes in the level of connectivity between the ER and the mitochondria $[176,177]$.

\section{Conclusions}

As the most direct communicating medium between the ER and the mitochondria, MAMs play an important role in coordinating the multiple array of functions carried out by these two organelles, particularly the integration of apoptotic signals. The ER is the main site for intracellular protein modification, $\mathrm{Ca}^{2+}$ storage, and lipid synthesis. It is also evident that the ER is more susceptible to various stresses, and therefore plays a key role as a stress sensor and provides an initial response to stress. Mitochondria play an irreplaceable role in important cellular processes such as energy metabolism and apoptosis; consequently, it is logical that the mitochondria work downstream of the stress response. MAMs are located directly between these two organelles and are tightly involved in the transduction of stress signals from the ER to the mitochondria; in some cases, they transmit apoptotic signals back to the ER. This not only ensures the complementarity of the functions between 
the two organelles, but also amplifies apoptotic signals between the two organelles, thus promoting coordinated functional responses. Clarifying this process will provide a new perspective for the study of pathological mechanisms, such as tumors, neurodegenerative diseases, and aging.

Although some progress has been made in the study of MAMs over recent years, there are still some uncertainties that need to be addressed. First, in terms of structure, some proteins are directly involved in the maintenance of MAMs structure, while others work as regulators for structural maintenance. However, little is known about such proteins or how they can be delineated between the two organelles with respect to functionality. Second, in terms of function, especially in the regulation of $\mathrm{Ca}^{2+}$ transfer, the width of the gap between the ER and the mitochondria plays an important role. However, interfering SERCAs or IP3Rs can also affects the transfer of $\mathrm{Ca}^{2+}$. It is still not clear whether the proteins that can affect $\mathrm{Ca}^{2+}$ transfer in MAMs work by changing the tightness of the gap within MAMs or by disturbing the function of SERCA/IP3Rs. These unresolved issues will be an important direction for future research.

Author Contributions: N.W.: writing the original draft; C.W.: drawing figures; H.Z.: literature searching; Y.H.: review and editing; B.L.: review and editing; L.S.: review, study design and funding acquisition; Y.G.: conceptualization, project administration, funding acquisition. All authors have read and agreed to the published version of the manuscript.

Funding: This work was funded by: Department of Science and Technology of Jilin Province (20180101136JC), Department of Finance of Jilin Province (2018SCZ030), the Education Department of Jilin Province (JJKH20190005KJ), Development and Reform Commission Engineering Laboratory Project of Jilin Province (2019C031), the Lateral Research Funds of Jilin University (2015377), National Natural Science Foundation of China (81772794, 81472419).

Acknowledgments: The authors would like to thank the Department of Pathophysiology, Jilin University for the generous support to the research that has been conducted.

Conflicts of Interest: The authors declare no conflict of interest.

$\begin{array}{ll}\text { Abbreviations } & \\ \text { ACAT1/SOAT1 } & \text { Acyl-Coenzyme A: Cholesterol Acyltransferase-1 } \\ \text { ACS } & \text { Fatty acid CoA ligase } \\ \text { AD } & \text { Alzheimer's disease } \\ \text { AIF } & \text { Apoptosis inducing factor } \\ \text { Akt } & \text { Serine/threonine-protein kinases } \\ \text { ALS } & \text { Amyotrophic lateral sclerosis } \\ \text { ATAD3A } & \text { ATPase family AAA domain-containing protein 3A } \\ \text { ATF4 } & \text { Activating Transcription Factor 4 } \\ \text { BAP31 } & \text { B-cell receptor associated protein 31 } \\ \text { Bip } & \text { Immunoglobulin heavy chain binding protein } \\ \text { BRCA1 } & \text { Breast cancer susceptibility gene } \\ \text { CypD } & \text { Cyclophilin D } \\ \text { IRE1 } & \text { Inositol-requiring enzyme 1 } \\ \text { eIF2 } \alpha & \text { eukaryotic Initiation Factor } 2 \alpha \\ \text { ER } & \text { Endoplasmic reticulum } \\ \text { ERO1 } \alpha & \text { Endoplasmic reticulum oxidoreductase 1- } \alpha \\ \text { ERS } & \text { Endoplasmic reticulum stress } \\ \text { ETC } & \text { Electron transport chain } \\ \text { FADD } & \text { Fas-associating protein with a novel death domain } \\ \text { FasL } & \text { Fas ligand } \\ \text { FATE1 } & \text { Fetal and adult testis expressed 1 } \\ \text { Fis1 } & \text { Mitochondrial fission 1 }\end{array}$




\begin{tabular}{|c|c|}
\hline FTD & Frontotemporal dementia \\
\hline FUNDC1 & FUN14 domain containing 1 \\
\hline FUS & Fused in sarcoma \\
\hline Grp75 & 75 KDa Glucose-regulated protein \\
\hline GSK-3b & Glycogen synthase kinase 3 beta \\
\hline IP3Rs & Inositol1,4,5-trisphosphatereceptors \\
\hline MAMs & Mitochondria associated membranes \\
\hline MCU & Mitochondrial $\mathrm{Ca}(2+)$ uniporter \\
\hline Mfn1/2 & Mitofusins $1 / 2$ \\
\hline MOSPD2 & Motile sperm domain-containing protein 2 \\
\hline mPTP & Mitochondrial permeability transition pore \\
\hline mTORC2 & Mammalian target of rapamycin complex2 \\
\hline NCS1 & Nucleobase cation symporter-1 \\
\hline NF- $\kappa \mathrm{B}$ & Nuclear factor kappa B \\
\hline PACS2 & Phosphoacidic cluster sorting protein 2 \\
\hline PD & Parkinson's disease \\
\hline PDK4 & Pyruvate dehydrogenase kinase 4 \\
\hline PERK & Protein kinase R (PKR)-like endoplasmic reticulum kinase \\
\hline PTPIP51 & Protein tyrosine phosphatase interacting protein 51 \\
\hline REEP1 & Receptor expression-enhancing protein 1 \\
\hline ROS & Reactive oxygen species \\
\hline RyRs & Ryanodine receptors \\
\hline SEPN1 & Selenoprotein $\mathrm{N}$ \\
\hline SERCAs & Sarco(endo)plasmic reticulum calcium-ATPases \\
\hline Sig-R & ECF sigma factor sigma(R) \\
\hline S1Ts & Exon 4 and/or exon 11 spliced SERCA1 splice variants \\
\hline TDP-43 & TAR DNA binding protein 43 \\
\hline TG2 & Transglutaminase 2 \\
\hline TMX1 & Transmembrane thioredoxin-related protein 1 \\
\hline TNFR1 & Tumor necrosis factor receptor 1 \\
\hline TpMs & Trichoplein keratin filament binding protein \\
\hline TRADD & TNF receptor-associated death domain \\
\hline VABP & Vitamin A binding protein \\
\hline VDAC & Voltage-dependent anion channel \\
\hline WASF3 & Wiskott-Aldridge syndrome family 3 \\
\hline WFS1 & Wolfram syndrome type 1 \\
\hline XBP1 & X-box binding protein 1 \\
\hline
\end{tabular}

\section{References}

1. Elmore, S. Apoptosis: A review of programmed cell death. Toxicol. Pathol. 2007, 35, 495-516. [CrossRef]

2. Santucci, R.; Sinibaldi, F.; Cozza, P.; Polticelli, F.; Fiorucci, L. Cytochrome c: An extreme multifunctional protein with a key role in cell fate. Int. J. Biol. Macromol. 2019, 136, 1237-1246. [CrossRef] [PubMed]

3. Korga, A.; Korobowicz, E.; Dudka, J. Role of mitochondrial protein Smac/Diablo in regulation of apoptotic pathways. Pol. Merkur. Lekarski 2006, 20, 573-576. [PubMed]

4. Vande Walle, L.; Lamkanfi, M.; Vandenabeele, P. The mitochondrial serine protease HtrA2/Omi: An overview. Cell Death Differ. 2008, 15, 453-460. [CrossRef] [PubMed]

5. Bano, D.; Prehn, J.H.M. Apoptosis-Inducing Factor (AIF) in Physiology and Disease: The Tale of a Repented Natural Born Killer. EBioMedicine 2018, 30, 29-37. [CrossRef]

6. Low, R.L. Mitochondrial Endonuclease G function in apoptosis and mtDNA metabolism: A historical perspective. Mitochondrion 2003, 2, 225-236. [CrossRef]

7. Larsen, B.D.; Sorensen, C.S. The caspase-activated DNase: Apoptosis and beyond. FEBS J. 2017, 284, 1160-1170. [CrossRef] [PubMed]

8. D'Arcy, M.S. Cell death: A review of the major forms of apoptosis, necrosis and autophagy. Cell Biol. Int. 2019, 43, 582-592. [CrossRef]

9. Kantari, C.; Walczak, H. Caspase-8 and bid: Caught in the act between death receptors and mitochondria. Biochim. Biophys. Acta 2011, 1813, 558-563. [CrossRef] [PubMed]

10. Huang, K.; Zhang, J.; O’Neill, K.L.; Gurumurthy, C.B.; Quadros, R.M.; Tu, Y.; Luo, X. Cleavage by Caspase 8 and Mitochondrial Membrane Association Activate the BH3-only Protein Bid during TRAIL-induced Apoptosis. J. Biol. Chem. 2016, 291 , 11843-11851. [CrossRef] 
11. Voskoboinik, I.; Whisstock, J.C.; Trapani, J.A. Perforin and granzymes: Function, dysfunction and human pathology. Nat. Rev. Immunol. 2015, 15, 388-400. [CrossRef] [PubMed]

12. Hassan, M.; Watari, H.; AbuAlmaaty, A.; Ohba, Y.; Sakuragi, N. Apoptosis and molecular targeting therapy in cancer. Biomed. Res. Int. 2014, 2014, 150845. [CrossRef]

13. Siddiqui, W.A.; Ahad, A.; Ahsan, H. The mystery of BCL2 family: Bcl-2 proteins and apoptosis: An update. Arch. Toxicol. 2015, 89, 289-317. [CrossRef]

14. Kim, H.; Rafiuddin-Shah, M.; Tu, H.C.; Jeffers, J.R.; Zambetti, G.P.; Hsieh, J.J.; Cheng, E.H. Hierarchical regulation of mitochondrion-dependent apoptosis by BCL-2 subfamilies. Nat. Cell Biol. 2006, 8, 1348-1358. [CrossRef]

15. Schwarz, D.S.; Blower, M.D. The endoplasmic reticulum: Structure, function and response to cellular signaling. Cell. Mol. Life Sci. 2016, 73, 79-94. [CrossRef] [PubMed]

16. Braakman, I.; Hebert, D.N. Protein folding in the endoplasmic reticulum. Cold Spring Harb. Perspect. Biol. 2013,5 , a013201. [CrossRef]

17. Quon, E.; Sere, Y.Y.; Chauhan, N.; Johansen, J.; Sullivan, D.P.; Dittman, J.S.; Rice, W.J.; Chan, R.B.; Di Paolo, G.; Beh, C.T.; et al. Endoplasmic reticulum-plasma membrane contact sites integrate sterol and phospholipid regulation. PLoS Biol. 2018, 16, e2003864. [CrossRef] [PubMed]

18. Islam, M.S. Calcium Signaling: From Basic to Bedside. Adv. Exp. Med. Biol. 2020, 1131, 1-6. [CrossRef]

19. Annesley, S.J.; Fisher, P.R. Mitochondria in Health and Disease. Cells 2019, 8, 680. [CrossRef] [PubMed]

20. Desagher, S.; Martinou, J.C. Mitochondria as the central control point of apoptosis. Trends Cell Biol. 2000, 10, 369-377. [CrossRef]

21. Galluzzi, L.; Kepp, O.; Trojel-Hansen, C.; Kroemer, G. Mitochondrial control of cellular life, stress, and death. Circ. Res. 2012, 111, 1198-1207. [CrossRef]

22. Doghman-Bouguerra, M.; Lalli, E. ER-mitochondria interactions: Both strength and weakness within cancer cells. Biochim. Biophys. Acta Mol. Cell Res. 2019, 1866, 650-662. [CrossRef]

23. Bernhard, W.; Rouiller, C. Close topographical relationship between mitochondria and ergastoplasm of liver cells in a definite phase of cellular activity. J. Biophys. Biochem. Cytol. 1956, 2, 73-78. [CrossRef] [PubMed]

24. Mannella, C.A. The relevance of mitochondrial membrane topology to mitochondrial function. Biochim. Biophys. Acta 2006, 1762, 140-147. [CrossRef] [PubMed]

25. Rizzuto, R.; Pinton, P.; Carrington, W.; Fay, F.S.; Fogarty, K.E.; Lifshitz, L.M.; Tuft, R.A.; Pozzan, T. Close contacts with the endoplasmic reticulum as determinants of mitochondrial $\mathrm{Ca}^{2+}$ responses. Science 1998, 280, 1763-1766. [CrossRef]

26. Marchi, S.; Patergnani, S.; Missiroli, S.; Morciano, G.; Rimessi, A.; Wieckowski, M.R.; Giorgi, C.; Pinton, P. Mitochondrial and endoplasmic reticulum calcium homeostasis and cell death. Cell Calcium 2018, 69, 62-72. [CrossRef]

27. Iurlaro, R.; Munoz-Pinedo, C. Cell death induced by endoplasmic reticulum stress. FEBS J. 2016, 283, 2640-2652. [CrossRef]

28. Gardner, B.M.; Pincus, D.; Gotthardt, K.; Gallagher, C.M.; Walter, P. Endoplasmic reticulum stress sensing in the unfolded protein response. Cold Spring Harb. Perspect. Biol. 2013, 5, a013169. [CrossRef] [PubMed]

29. Giacomello, M.; Pellegrini, L. The coming of age of the mitochondria-ER contact: A matter of thickness. Cell Death Differ. 2016, 23, 1417-1427. [CrossRef] [PubMed]

30. Filadi, R.; Theurey, P.; Pizzo, P. The endoplasmic reticulum-mitochondria coupling in health and disease: Molecules, functions and significance. Cell Calcium 2017, 62, 1-15. [CrossRef]

31. Csordas, G.; Renken, C.; Varnai, P.; Walter, L.; Weaver, D.; Buttle, K.F.; Balla, T.; Mannella, C.A.; Hajnoczky, G. Structural and functional features and significance of the physical linkage between ER and mitochondria. J. Cell Biol. 2006, 174, 915-921. [CrossRef]

32. Zhang, A.; Williamson, C.D.; Wong, D.S.; Bullough, M.D.; Brown, K.J.; Hathout, Y.; Colberg-Poley, A.M. Quantitative proteomic analyses of human cytomegalovirus-induced restructuring of endoplasmic reticulum-mitochondrial contacts at late times of infection. Mol. Cell. Proteom. 2011, 10, M111-009936. [CrossRef]

33. Poston, C.N.; Krishnan, S.C.; Bazemore-Walker, C.R. In-depth proteomic analysis of mammalian mitochondria-associated membranes (MAM). J. Proteom. 2013, 79, 219-230. [CrossRef] [PubMed]

34. Janikiewicz, J.; Szymanski, J.; Malinska, D.; Patalas-Krawczyk, P.; Michalska, B.; Duszynski, J.; Giorgi, C.; Bonora, M.; Dobrzyn, A.; Wieckowski, M.R. Mitochondria-associated membranes in aging and senescence: Structure, function, and dynamics. Cell Death Dis. 2018, 9, 332. [CrossRef] [PubMed]

35. Parys, J.B.; Vervliet, T. New Insights in the IP3 Receptor and Its Regulation. Adv. Exp. Med. Biol. 2020, 1131, 243-270. [CrossRef]

36. Tada, M.; Nishizawa, M.; Onodera, O. Roles of inositol 1,4,5-trisphosphate receptors in spinocerebellar ataxias. Neurochem. Int. 2016, 94, 1-8. [CrossRef]

37. Mazure, N.M. VDAC in cancer. Biochim. Biophys. Acta Bioenerg. 2017, 1858, 665-673. [CrossRef]

38. Szabadkai, G.; Bianchi, K.; Varnai, P.; De Stefani, D.; Wieckowski, M.R.; Cavagna, D.; Nagy, A.I.; Balla, T.; Rizzuto, R. Chaperonemediated coupling of endoplasmic reticulum and mitochondrial Ca ${ }^{2+}$ channels. J. Cell Biol. 2006, 175, 901-911. [CrossRef] [PubMed]

39. Rapizzi, E.; Pinton, P.; Szabadkai, G.; Wieckowski, M.R.; Vandecasteele, G.; Baird, G.; Tuft, R.A.; Fogarty, K.E.; Rizzuto, R. Recombinant expression of the voltage-dependent anion channel enhances the transfer of $\mathrm{Ca}^{2+}$ microdomains to mitochondria. $J$. Cell Biol. 2002, 159, 613-624. [CrossRef] [PubMed] 
40. Tubbs, E.; Theurey, P.; Vial, G.; Bendridi, N.; Bravard, A.; Chauvin, M.A.; Ji-Cao, J.; Zoulim, F.; Bartosch, B.; Ovize, M.; et al. Mitochondria-associated endoplasmic reticulum membrane (MAM) integrity is required for insulin signaling and is implicated in hepatic insulin resistance. Diabetes 2014, 63, 3279-3294. [CrossRef] [PubMed]

41. Honrath, B.; Metz, I.; Bendridi, N.; Rieusset, J.; Culmsee, C.; Dolga, A.M. Glucose-regulated protein 75 determines ERmitochondrial coupling and sensitivity to oxidative stress in neuronal cells. Cell Death Discov. 2017, 3, 17076. [CrossRef]

42. Thoudam, T.; Ha, C.M.; Leem, J.; Chanda, D.; Park, J.S.; Kim, H.J.; Jeon, J.H.; Choi, Y.K.; Liangpunsakul, S.; Huh, Y.H.; et al. PDK4 Augments ER-Mitochondria Contact to Dampen Skeletal Muscle Insulin Signaling during Obesity. Diabetes 2019, 68, 571-586. [CrossRef] [PubMed]

43. Vinay Kumar, C.; Kumar, K.M.; Swetha, R.; Ramaiah, S.; Anbarasu, A. Protein aggregation due to nsSNP resulting in P56S VABP protein is associated with amyotrophic lateral sclerosis. J. Theor. Biol. 2014, 354, 72-80. [CrossRef] [PubMed]

44. Kanekura, K.; Nishimoto, I.; Aiso, S.; Matsuoka, M. Characterization of amyotrophic lateral sclerosis-linked P56S mutation of vesicle-associated membrane protein-associated protein B (VAPB/ALS8). J. Biol. Chem. 2006, 281, 30223-30233. [CrossRef]

45. De Vos, K.J.; Morotz, G.M.; Stoica, R.; Tudor, E.L.; Lau, K.F.; Ackerley, S.; Warley, A.; Shaw, C.E.; Miller, C.C. VAPB interacts with the mitochondrial protein PTPIP51 to regulate calcium homeostasis. Hum. Mol. Genet. 2012, 21, 1299-1311. [CrossRef] [PubMed]

46. Stoica, R.; De Vos, K.J.; Paillusson, S.; Mueller, S.; Sancho, R.M.; Lau, K.F.; Vizcay-Barrena, G.; Lin, W.L.; Xu, Y.F.; Lewis, J.; et al. ER-mitochondria associations are regulated by the VAPB-PTPIP51 interaction and are disrupted by ALS/FTD-associated TDP-43. Nat. Commun. 2014, 5, 3996. [CrossRef] [PubMed]

47. Qiao, X.; Jia, S.; Ye, J.; Fang, X.; Zhang, C.; Cao, Y.; Xu, C.; Zhao, L.; Zhu, Y.; Wang, L.; et al. PTPIP51 regulates mouse cardiac ischemia/reperfusion through mediating the mitochondria-SR junction. Sci. Rep. 2017, 7, 45379. [CrossRef]

48. Formosa, L.E.; Ryan, M.T. Mitochondrial fusion: Reaching the end of mitofusin's tether. J. Cell Biol. 2016, 215, 597-598. [CrossRef] [PubMed]

49. de Brito, O.M.; Scorrano, L. Mitofusin 2 tethers endoplasmic reticulum to mitochondria. Nature 2008, 456, 605-610. [CrossRef] [PubMed]

50. Alford, S.C.; Ding, Y.; Simmen, T.; Campbell, R.E. Dimerization-dependent green and yellow fluorescent proteins. ACS Synth. Biol. 2012, 1, 569-575. [CrossRef]

51. Naon, D.; Zaninello, M.; Giacomello, M.; Varanita, T.; Grespi, F.; Lakshminaranayan, S.; Serafini, A.; Semenzato, M.; Herkenne, S.; Hernandez-Alvarez, M.I.; et al. Critical reappraisal confirms that Mitofusin 2 is an endoplasmic reticulum-mitochondria tether. Proc. Natl. Acad. Sci. USA 2016, 113, 11249-11254. [CrossRef]

52. Cosson, P.; Marchetti, A.; Ravazzola, M.; Orci, L. Mitofusin-2 independent juxtaposition of endoplasmic reticulum and mitochondria: An ultrastructural study. PLoS ONE 2012, 7, e46293. [CrossRef] [PubMed]

53. Filadi, R.; Greotti, E.; Turacchio, G.; Luini, A.; Pozzan, T.; Pizzo, P. Mitofusin 2 ablation increases endoplasmic reticulummitochondria coupling. Proc. Natl. Acad. Sci. USA 2015, 112, E2174-E2181. [CrossRef] [PubMed]

54. Herrera-Cruz, M.S.; Simmen, T. Cancer: Untethering Mitochondria from the Endoplasmic Reticulum? Front. Oncol. 2017, 7, 105. [CrossRef] [PubMed]

55. Di Mattia, T.; Wilhelm, L.P.; Ikhlef, S.; Wendling, C.; Spehner, D.; Nomine, Y.; Giordano, F.; Mathelin, C.; Drin, G.; Tomasetto, C.; et al. Identification of MOSPD2, a novel scaffold for endoplasmic reticulum membrane contact sites. EMBO Rep. 2018, 19. [CrossRef]

56. Lim, Y.; Cho, I.T.; Schoel, L.J.; Cho, G.; Golden, J.A. Hereditary spastic paraplegia-linked REEP1 modulates endoplasmic reticulum/mitochondria contacts. Ann. Neurol. 2015, 78, 679-696. [CrossRef]

57. Guardia-Laguarta, C.; Area-Gomez, E.; Rub, C.; Liu, Y.; Magrane, J.; Becker, D.; Voos, W.; Schon, E.A.; Przedborski, S. alphaSynuclein is localized to mitochondria-associated ER membranes. J. Neurosci. 2014, 34, 249-259. [CrossRef] [PubMed]

58. Cali, T.; Ottolini, D.; Negro, A.; Brini, M. alpha-Synuclein controls mitochondrial calcium homeostasis by enhancing endoplasmic reticulum-mitochondria interactions. J. Biol. Chem. 2012, 287, 17914-17929. [CrossRef] [PubMed]

59. Gomez-Suaga, P.; Bravo-San Pedro, J.M.; Gonzalez-Polo, R.A.; Fuentes, J.M.; Niso-Santano, M. ER-mitochondria signaling in Parkinson's disease. Cell Death Dis. 2018, 9, 337. [CrossRef]

60. Ottolini, D.; Cali, T.; Negro, A.; Brini, M. The Parkinson disease-related protein DJ-1 counteracts mitochondrial impairment induced by the tumour suppressor protein $\mathrm{p} 53$ by enhancing endoplasmic reticulum-mitochondria tethering. Hum. Mol. Genet. 2013, 22, 2152-2168. [CrossRef] [PubMed]

61. Liu, Y.; Ma, X.; Fujioka, H.; Liu, J.; Chen, S.; Zhu, X. DJ-1 regulates the integrity and function of ER-mitochondria association through interaction with IP3R3-Grp75-VDAC1. Proc. Natl. Acad. Sci. USA 2019, 116, 25322-25328. [CrossRef] [PubMed]

62. Stoica, R.; Paillusson, S.; Gomez-Suaga, P.; Mitchell, J.C.; Lau, D.H.; Gray, E.H.; Sancho, R.M.; Vizcay-Barrena, G.; De Vos, K.J.; Shaw, C.E.; et al. ALS/FTD-associated FUS activates GSK-3beta to disrupt the VAPB-PTPIP51 interaction and ER-mitochondria associations. EMBO Rep. 2016, 17, 1326-1342. [CrossRef]

63. D'Eletto, M.; Rossin, F.; Occhigrossi, L.; Farrace, M.G.; Faccenda, D.; Desai, R.; Marchi, S.; Refolo, G.; Falasca, L.; Antonioli, M.; et al. Transglutaminase Type 2 Regulates ER-Mitochondria Contact Sites by Interacting with GRP75. Cell Rep. 2018, 25, 3573-3581 e3574. [CrossRef]

64. Cerqua, C.; Anesti, V.; Pyakurel, A.; Liu, D.; Naon, D.; Wiche, G.; Baffa, R.; Dimmer, K.S.; Scorrano, L. Trichoplein/mitostatin regulates endoplasmic reticulum-mitochondria juxtaposition. EMBO Rep. 2010, 11, 854-860. [CrossRef] 
65. Paillard, M.; Tubbs, E.; Thiebaut, P.A.; Gomez, L.; Fauconnier, J.; Da Silva, C.C.; Teixeira, G.; Mewton, N.; Belaidi, E.; Durand, A.; et al. Depressing mitochondria-reticulum interactions protects cardiomyocytes from lethal hypoxia-reoxygenation injury. Circulation 2013, 128, 1555-1565. [CrossRef]

66. Wu, S.; Lu, Q.; Wang, Q.; Ding, Y.; Ma, Z.; Mao, X.; Huang, K.; Xie, Z.; Zou, M.H. Binding of FUN14 Domain Containing 1 With Inositol 1,4,5-Trisphosphate Receptor in Mitochondria-Associated Endoplasmic Reticulum Membranes Maintains Mitochondrial Dynamics and Function in Hearts In Vivo. Circulation 2017, 136, 2248-2266. [CrossRef] [PubMed]

67. Filadi, R.; Greotti, E.; Turacchio, G.; Luini, A.; Pozzan, T.; Pizzo, P. Presenilin 2 Modulates Endoplasmic Reticulum-Mitochondria Coupling by Tuning the Antagonistic Effect of Mitofusin 2. Cell Rep. 2016, 15, 2226-2238. [CrossRef] [PubMed]

68. Doghman-Bouguerra, M.; Granatiero, V.; Sbiera, S.; Sbiera, I.; Lacas-Gervais, S.; Brau, F.; Fassnacht, M.; Rizzuto, R.; Lalli, E. FATE1 antagonizes calcium- and drug-induced apoptosis by uncoupling ER and mitochondria. EMBO Rep. 2016, 17, 1264-1280. [CrossRef]

69. Sutendra, G.; Dromparis, P.; Wright, P.; Bonnet, S.; Haromy, A.; Hao, Z.; McMurtry, M.S.; Michalak, M.; Vance, J.E.; Sessa, W.C.; et al. The role of Nogo and the mitochondria-endoplasmic reticulum unit in pulmonary hypertension. Sci. Transl. Med. 2011, 3, 88ra55. [CrossRef] [PubMed]

70. Munoz, J.P.; Ivanova, S.; Sanchez-Wandelmer, J.; Martinez-Cristobal, P.; Noguera, E.; Sancho, A.; Diaz-Ramos, A.; HernandezAlvarez, M.I.; Sebastian, D.; Mauvezin, C.; et al. Mfn2 modulates the UPR and mitochondrial function via repression of PERK. EMBO J. 2013, 32, 2348-2361. [CrossRef] [PubMed]

71. van Vliet, A.R.; Agostinis, P. When under pressure, get closer: PERKing up membrane contact sites during ER stress. Biochem. Soc. Trans. 2016, 44, 499-504. [CrossRef] [PubMed]

72. Veeresh, P.; Kaur, H.; Sarmah, D.; Mounica, L.; Verma, G.; Kotian, V.; Kesharwani, R.; Kalia, K.; Borah, A.; Wang, X.; et al. Endoplasmic reticulum-mitochondria crosstalk: From junction to function across neurological disorders. Ann. N. Y. Acad. Sci. 2019, 1457, 41-60. [CrossRef]

73. Bravo-Sagua, R.; Rodriguez, A.E.; Kuzmicic, J.; Gutierrez, T.; Lopez-Crisosto, C.; Quiroga, C.; Diaz-Elizondo, J.; Chiong, M.; Gillette, T.G.; Rothermel, B.A.; et al. Cell death and survival through the endoplasmic reticulum-mitochondrial axis. Curr. Mol. Med. 2013, 13, 317-329. [CrossRef] [PubMed]

74. Chami, M.; Checler, F. Alterations of the Endoplasmic Reticulum (ER) Calcium Signaling Molecular Components in Alzheimer's Disease. Cells 2020, 9, 2577. [CrossRef] [PubMed]

75. Ivanova, H.; Vervliet, T.; Missiaen, L.; Parys, J.B.; De Smedt, H.; Bultynck, G. Inositol 1,4,5-trisphosphate receptor-isoform diversity in cell death and survival. Biochim. Biophys. Acta 2014, 1843, 2164-2183. [CrossRef] [PubMed]

76. Rizzuto, R.; Simpson, A.W.; Brini, M.; Pozzan, T. Rapid changes of mitochondrial Ca ${ }^{2+}$ revealed by specifically targeted recombinant aequorin. Nature 1992, 358, 325-327. [CrossRef]

77. Giacomello, M.; Drago, I.; Bortolozzi, M.; Scorzeto, M.; Gianelle, A.; Pizzo, P.; Pozzan, T. Ca ${ }^{2+}$ hot spots on the mitochondrial surface are generated by $\mathrm{Ca}^{2+}$ mobilization from stores, but not by activation of store-operated $\mathrm{Ca}^{2+}$ channels. Mol. Cell 2010, 38, 280-290. [CrossRef]

78. Brasen, J.C.; Olsen, L.F.; Hallett, M.B. Cell surface topology creates high $\mathrm{Ca}^{2+}$ signalling microdomains. Cell Calcium 2010, 47, 339-349. [CrossRef] [PubMed]

79. Belosludtsev, K.N.; Dubinin, M.V.; Belosludtseva, N.V.; Mironova, G.D. Mitochondrial Ca ${ }^{2+}$ Transport: Mechanisms, Molecular Structures, and Role in Cells. Biochemistry 2019, 84, 593-607. [CrossRef]

80. Territo, P.R.; Mootha, V.K.; French, S.A.; Balaban, R.S. Ca ${ }^{2+}$ activation of heart mitochondrial oxidative phosphorylation: Role of the $\mathrm{F}_{0} / \mathrm{F}_{1}$-ATPase. Am. J. Physiol. Cell Physiol. 2000, 278, C423-C435. [CrossRef]

81. Glancy, B.; Willis, W.T.; Chess, D.J.; Balaban, R.S. Effect of calcium on the oxidative phosphorylation cascade in skeletal muscle mitochondria. Biochemistry 2013, 52, 2793-2809. [CrossRef]

82. Mitani, Y.; Behrooz, A.; Dubyak, G.R.; Ismail-Beigi, F. Stimulation of GLUT-1 glucose transporter expression in response to exposure to calcium ionophore A-23187. Am. J. Physiol. 1995, 269, C1228-C1234. [CrossRef]

83. Galluzzi, L.; Vitale, I.; Aaronson, S.A.; Abrams, J.M.; Adam, D.; Agostinis, P.; Alnemri, E.S.; Altucci, L.; Amelio, I.; Andrews, D.W.; et al. Molecular mechanisms of cell death: Recommendations of the Nomenclature Committee on Cell Death 2018. Cell Death Differ. 2018, 25, 486-541. [CrossRef]

84. Giorgi, C.; Baldassari, F.; Bononi, A.; Bonora, M.; De Marchi, E.; Marchi, S.; Missiroli, S.; Patergnani, S.; Rimessi, A.; Suski, J.M.; et al. Mitochondrial $\mathrm{Ca}^{2+}$ and apoptosis. Cell Calcium 2012, 52, 36-43. [CrossRef]

85. Pinton, P.; Ferrari, D.; Rapizzi, E.; Di Virgilio, F.; Pozzan, T.; Rizzuto, R. The $\mathrm{Ca}^{2+}$ concentration of the endoplasmic reticulum is a key determinant of ceramide-induced apoptosis: Significance for the molecular mechanism of Bcl-2 action. EMBO J. 2001, 20, 2690-2701. [CrossRef]

86. Carraro, M.; Jones, K.; Sartori, G.; Schiavone, M.; Antonucci, S.; Kucharczyk, R.; di Rago, J.P.; Franchin, C.; Arrigoni, G.; Forte, M.; et al. The Unique Cysteine of F-ATP Synthase OSCP Subunit Participates in Modulation of the Permeability Transition Pore. Cell Rep. 2020, 32, 108095. [CrossRef] [PubMed]

87. Hwang, M.S.; Schwall, C.T.; Pazarentzos, E.; Datler, C.; Alder, N.N.; Grimm, S. Mitochondrial Ca ${ }^{2+}$ influx targets cardiolipin to disintegrate respiratory chain complex II for cell death induction. Cell Death Differ. 2014, 21, 1733-1745. [CrossRef]

88. Marchi, S.; Marinello, M.; Bononi, A.; Bonora, M.; Giorgi, C.; Rimessi, A.; Pinton, P. Selective modulation of subtype III IP ${ }_{3}$ R by Akt regulates ER Ca ${ }^{2+}$ release and apoptosis. Cell Death Dis. 2012, 3, e304. [CrossRef] [PubMed] 
89. Szado, T.; Vanderheyden, V.; Parys, J.B.; De Smedt, H.; Rietdorf, K.; Kotelevets, L.; Chastre, E.; Khan, F.; Landegren, U.; Soderberg, O.; et al. Phosphorylation of inositol 1,4,5-trisphosphate receptors by protein kinase B/Akt inhibits Ca ${ }^{2+}$ release and apoptosis. Proc. Natl. Acad. Sci. USA 2008, 105, 2427-2432. [CrossRef] [PubMed]

90. Marchi, S.; Rimessi, A.; Giorgi, C.; Baldini, C.; Ferroni, L.; Rizzuto, R.; Pinton, P. Akt kinase reducing endoplasmic reticulum Ca ${ }^{2+}$ release protects cells from $\mathrm{Ca}^{2+}$-dependent apoptotic stimuli. Biochem. Biophys. Res. Commun. 2008, 375, 501-505. [CrossRef] [PubMed]

91. Betz, C.; Stracka, D.; Prescianotto-Baschong, C.; Frieden, M.; Demaurex, N.; Hall, M.N. Feature Article: mTOR complex 2-Akt signaling at mitochondria-associated endoplasmic reticulum membranes (MAM) regulates mitochondrial physiology. Proc. Natl. Acad. Sci. USA 2013, 110, 12526-12534. [CrossRef]

92. Hagiwara, A.; Cornu, M.; Cybulski, N.; Polak, P.; Betz, C.; Trapani, F.; Terracciano, L.; Heim, M.H.; Ruegg, M.A.; Hall, M.N. Hepatic mTORC2 activates glycolysis and lipogenesis through Akt, glucokinase, and SREBP1c. Cell Metab. 2012, 15, 725-738. [CrossRef]

93. Giorgi, C.; Ito, K.; Lin, H.K.; Santangelo, C.; Wieckowski, M.R.; Lebiedzinska, M.; Bononi, A.; Bonora, M.; Duszynski, J.; Bernardi, R.; et al. PML regulates apoptosis at endoplasmic reticulum by modulating calcium release. Science 2010, 330, $1247-1251$. [CrossRef]

94. Bononi, A.; Bonora, M.; Marchi, S.; Missiroli, S.; Poletti, F.; Giorgi, C.; Pandolfi, P.P.; Pinton, P. Identification of PTEN at the ER and MAMs and its regulation of $\mathrm{Ca}^{2+}$ signaling and apoptosis in a protein phosphatase-dependent manner. Cell Death Differ. 2013, 20, 1631-1643. [CrossRef] [PubMed]

95. Monaco, G.; Decrock, E.; Akl, H.; Ponsaerts, R.; Vervliet, T.; Luyten, T.; De Maeyer, M.; Missiaen, L.; Distelhorst, C.W.; De Smedt, $\mathrm{H}$; ; et al. Selective regulation of IP3-receptor-mediated $\mathrm{Ca}^{2+}$ signaling and apoptosis by the $\mathrm{BH} 4$ domain of $\mathrm{Bcl}-2$ versus $\mathrm{Bcl}-\mathrm{Xl}$. Cell Death Differ. 2012, 19, 295-309. [CrossRef] [PubMed]

96. Arbel, N.; Shoshan-Barmatz, V. Voltage-dependent anion channel 1-based peptides interact with Bcl-2 to prevent antiapoptotic activity. J. Biol. Chem. 2010, 285, 6053-6062. [CrossRef]

97. Eckenrode, E.F.; Yang, J.; Velmurugan, G.V.; Foskett, J.K.; White, C. Apoptosis protection by Mcl-1 and Bcl-2 modulation of inositol 1,4,5-trisphosphate receptor-dependent $\mathrm{Ca}^{2+}$ signaling. J. Biol. Chem. 2010, 285, 13678-13684. [CrossRef]

98. Huang, H.; Shah, K.; Bradbury, N.A.; Li, C.; White, C. Mcl-1 promotes lung cancer cell migration by directly interacting with VDAC to increase mitochondrial $\mathrm{Ca}^{2+}$ uptake and reactive oxygen species generation. Cell Death Dis. 2014, 5, e1482. [CrossRef] [PubMed]

99. Schulman, J.J.; Wright, F.A.; Kaufmann, T.; Wojcikiewicz, R.J. The Bcl-2 protein family member Bok binds to the coupling domain of inositol 1,4,5-trisphosphate receptors and protects them from proteolytic cleavage. J. Biol. Chem. 2013, 288, 25340-25349. [CrossRef]

100. Assefa, Z.; Bultynck, G.; Szlufcik, K.; Nadif Kasri, N.; Vermassen, E.; Goris, J.; Missiaen, L.; Callewaert, G.; Parys, J.B.; De Smedt, H. Caspase-3-induced truncation of type 1 inositol trisphosphate receptor accelerates apoptotic cell death and induces inositol trisphosphate-independent calcium release during apoptosis. J. Biol. Chem. 2004, 279, 43227-43236. [CrossRef]

101. Lewis, A.; Hayashi, T.; Su, T.P.; Betenbaugh, M.J. Bcl-2 family in inter-organelle modulation of calcium signaling; roles in bioenergetics and cell survival. J. Bioenerg. Biomembr. 2014, 46, 1-15. [CrossRef]

102. Cai, Y.; Yang, L.; Niu, F.; Liao, K.; Buch, S. Role of Sigma-1 Receptor in Cocaine Abuse and Neurodegenerative Disease. Adv. Exp. Med. Biol. 2017, 964, 163-175. [CrossRef]

103. Hayashi, T.; Su, T.P. Sigma-1 receptor chaperones at the ER-mitochondrion interface regulate $\mathrm{Ca}^{2+}$ signaling and cell survival. Cell 2007, 131, 596-610. [CrossRef] [PubMed]

104. Raggi, C.; Diociaiuti, M.; Caracciolo, G.; Fratini, F.; Fantozzi, L.; Piccaro, G.; Fecchi, K.; Pizzi, E.; Marano, G.; Ciaffoni, F.; et al. Caveolin-1 Endows Order in Cholesterol-Rich Detergent Resistant Membranes. Biomolecules 2019, 9, 287. [CrossRef] [PubMed]

105. Sundivakkam, P.C.; Kwiatek, A.M.; Sharma, T.T.; Minshall, R.D.; Malik, A.B.; Tiruppathi, C. Caveolin-1 scaffold domain interacts with TRPC1 and IP3R3 to regulate $\mathrm{Ca}^{2+}$ store release-induced $\mathrm{Ca}^{2+}$ entry in endothelial cells. Am. J. Physiol. Cell Physiol. 2009, 296, C403-C413. [CrossRef] [PubMed]

106. Rimessi, A.; Marchi, S.; Patergnani, S.; Pinton, P. H-Ras-driven tumoral maintenance is sustained through caveolin-1-dependent alterations in calcium signaling. Oncogene 2014, 33, 2329-2340. [CrossRef]

107. Hedgepeth, S.C.; Garcia, M.I.; Wagner, L.E., 2nd; Rodriguez, A.M.; Chintapalli, S.V.; Snyder, R.R.; Hankins, G.D.; Henderson, B.R.; Brodie, K.M.; Yule, D.I.; et al. The BRCA1 tumor suppressor binds to inositol 1,4,5-trisphosphate receptors to stimulate apoptotic calcium release. J. Biol. Chem. 2015, 290, 7304-7313. [CrossRef] [PubMed]

108. Angebault, C.; Fauconnier, J.; Patergnani, S.; Rieusset, J.; Danese, A.; Affortit, C.A.; Jagodzinska, J.; Megy, C.; Quiles, M.; Cazevieille, C.; et al. ER-mitochondria cross-talk is regulated by the $\mathrm{Ca}^{2+}$ sensor NCS1 and is impaired in Wolfram syndrome. Sci. Signal. 2018, 11. [CrossRef] [PubMed]

109. Delprat, B.; Maurice, T.; Delettre, C. Wolfram syndrome: MAMs' connection? Cell Death Dis. 2018, 9, 364. [CrossRef]

110. Matsuzaki, H.; Fujimoto, T.; Ota, T.; Ogawa, M.; Tsunoda, T.; Doi, K.; Hamabashiri, M.; Tanaka, M.; Shirasawa, S. Tespa1 is a novel inositol 1,4,5-trisphosphate receptor binding protein in T and B lymphocytes. FEBS Open Bio 2012, 2, 255-259. [CrossRef]

111. Matsuzaki, H.; Fujimoto, T.; Tanaka, M.; Shirasawa, S. Tespa1 is a novel component of mitochondria-associated endoplasmic reticulum membranes and affects mitochondrial calcium flux. Biochem. Biophys. Res. Commun. 2013, 433, 322-326. [CrossRef] [PubMed] 
112. Li, G.; Mongillo, M.; Chin, K.T.; Harding, H.; Ron, D.; Marks, A.R.; Tabas, I. Role of ERO1-alpha-mediated stimulation of inositol 1,4,5-triphosphate receptor activity in endoplasmic reticulum stress-induced apoptosis. J. Cell Biol. 2009, 186, 783-792. [CrossRef] [PubMed]

113. Giorgi, C.; Bonora, M.; Sorrentino, G.; Missiroli, S.; Poletti, F.; Suski, J.M.; Galindo Ramirez, F.; Rizzuto, R.; Di Virgilio, F.; Zito, E.; et al. p53 at the endoplasmic reticulum regulates apoptosis in a $\mathrm{Ca}^{2+}$-dependent manner. Proc. Natl. Acad. Sci. USA 2015, 112, 1779-1784. [CrossRef]

114. Giorgi, C.; Bonora, M.; Missiroli, S.; Poletti, F.; Ramirez, F.G.; Morciano, G.; Morganti, C.; Pandolfi, P.P.; Mammano, F.; Pinton, P. Intravital imaging reveals p53-dependent cancer cell death induced by phototherapy via calcium signaling. Oncotarget 2015, 6 , 1435-1445. [CrossRef] [PubMed]

115. Krols, M.; Bultynck, G.; Janssens, S. ER-Mitochondria contact sites: A new regulator of cellular calcium flux comes into play. J. Cell Biol. 2016, 214, 367-370. [CrossRef]

116. Raturi, A.; Gutierrez, T.; Ortiz-Sandoval, C.; Ruangkittisakul, A.; Herrera-Cruz, M.S.; Rockley, J.P.; Gesson, K.; Ourdev, D.; Lou, P.H.; Lucchinetti, E.; et al. TMX1 determines cancer cell metabolism as a thiol-based modulator of ER-mitochondria Ca ${ }^{2+}$ flux. J. Cell Biol. 2016, 214, 433-444. [CrossRef] [PubMed]

117. Dremina, E.S.; Sharov, V.S.; Kumar, K.; Zaidi, A.; Michaelis, E.K.; Schoneich, C. Anti-apoptotic protein Bcl-2 interacts with and destabilizes the sarcoplasmic/endoplasmic reticulum $\mathrm{Ca}^{2+}$-ATPase (SERCA). Biochem. J. 2004, 383, 361-370. [CrossRef] [PubMed]

118. Marino, M.; Stoilova, T.; Giorgi, C.; Bachi, A.; Cattaneo, A.; Auricchio, A.; Pinton, P.; Zito, E. SEPN1, an endoplasmic reticulumlocalized selenoprotein linked to skeletal muscle pathology, counteracts hyperoxidation by means of redox-regulating SERCA2 pump activity. Hum. Mol. Genet. 2015, 24, 1843-1855. [CrossRef]

119. Chami, M.; Gozuacik, D.; Lagorce, D.; Brini, M.; Falson, P.; Peaucellier, G.; Pinton, P.; Lecoeur, H.; Gougeon, M.L.; le Maire, M.; et al. SERCA1 truncated proteins unable to pump calcium reduce the endoplasmic reticulum calcium concentration and induce apoptosis. J. Cell Biol. 2001, 153, 1301-1314. [CrossRef]

120. Chami, M.; Oules, B.; Szabadkai, G.; Tacine, R.; Rizzuto, R.; Paterlini-Brechot, P. Role of SERCA1 truncated isoform in the proapoptotic calcium transfer from ER to mitochondria during ER stress. Mol. Cell 2008, 32, 641-651. [CrossRef]

121. Fayaz, S.M.; Raj, Y.V.; Krishnamurthy, R.G. CypD: The Key to the Death Door. CNS Neurol. Disord. Drug Targets 2015, 14, 654-663. [CrossRef]

122. Hijioka, M.; Inden, M.; Yanagisawa, D.; Kitamura, Y. DJ-1/PARK7: A New Therapeutic Target for Neurodegenerative Disorders. Biol. Pharm. Bull. 2017, 40, 548-552. [CrossRef] [PubMed]

123. Maxfield, K.E.; Taus, P.J.; Corcoran, K.; Wooten, J.; Macion, J.; Zhou, Y.; Borromeo, M.; Kollipara, R.K.; Yan, J.; Xie, Y.; et al. Comprehensive functional characterization of cancer-testis antigens defines obligate participation in multiple hallmarks of cancer. Nat. Commun. 2015, 6, 8840. [CrossRef] [PubMed]

124. Chen, M.; Chen, Z.; Wang, Y.; Tan, Z.; Zhu, C.; Li, Y.; Han, Z.; Chen, L.; Gao, R.; Liu, L.; et al. Mitophagy receptor FUNDC1 regulates mitochondrial dynamics and mitophagy. Autophagy 2016, 12, 689-702. [CrossRef] [PubMed]

125. Ohno, M. PERK as a hub of multiple pathogenic pathways leading to memory deficits and neurodegeneration in Alzheimer's disease. Brain Res. Bull. 2018, 141, 72-78. [CrossRef]

126. Leem, J.; Lee, I.K. Mechanisms of Vascular Calcification: The Pivotal Role of Pyruvate Dehydrogenase Kinase 4. Endocrinol. Metab. 2016, 31, 52-61. [CrossRef] [PubMed]

127. Chen, Q.; Schubert, D. Presenilin-interacting proteins. Expert Rev. Mol. Med. 2002, 4, 1-18. [CrossRef]

128. Ratti, A.; Buratti, E. Physiological functions and pathobiology of TDP-43 and FUS/TLS proteins. J. Neurochem. 2016, 138 (Suppl. 1), 95-111. [CrossRef]

129. Revathidevi, S.; Munirajan, A.K. Akt in cancer: Mediator and more. Semin. Cancer Biol. 2019, 59, 80-91. [CrossRef]

130. Schulman, J.J.; Szczesniak, L.M.; Bunker, E.N.; Nelson, H.A.; Roe, M.W.; Wagner, L.E., 2nd; Yule, D.I.; Wojcikiewicz, R.J.H. Bok regulates mitochondrial fusion and morphology. Cell Death Differ. 2019, 26, 2682-2694. [CrossRef]

131. Clark, S.L.; Rodriguez, A.M.; Snyder, R.R.; Hankins, G.D.; Boehning, D. Structure-Function Of The Tumor Suppressor BRCA1. Comput. Struct. Biotechnol. J. 2012, 1. [CrossRef]

132. Ketteler, J.; Klein, D. Caveolin-1, cancer and therapy resistance. Int. J. Cancer 2018, 143, 2092-2104. [CrossRef] [PubMed]

133. Shergalis, A.G.; Hu, S.; Bankhead, A., 3rd; Neamati, N. Role of the ERO1-PDI interaction in oxidative protein folding and disease. Pharmacol. Ther. 2020, 210, 107525. [CrossRef] [PubMed]

134. Yuan, T.; Lupse, B.; Maedler, K.; Ardestani, A. mTORC2 Signaling: A Path for Pancreatic beta Cell's Growth and Function. J. Mol. Biol. 2018, 430, 904-918. [CrossRef]

135. Boeckel, G.R.; Ehrlich, B.E. NCS-1 is a regulator of calcium signaling in health and disease. Biochim. Biophys. Acta Mol. Cell Res. 2018, 1865, 1660-1667. [CrossRef]

136. Hsu, K.S.; Kao, H.Y. PML: Regulation and multifaceted function beyond tumor suppression. Cell Biosci. 2018, 8, 5. [CrossRef]

137. Chen, C.Y.; Chen, J.; He, L.; Stiles, B.L. PTEN: Tumor Suppressor and Metabolic Regulator. Front. Endocrinol. $2018,9,338$. [CrossRef]

138. Slack, C. Ras signaling in aging and metabolic regulation. Nutr. Healthy Aging 2017, 4, 195-205. [CrossRef] [PubMed]

139. Penke, B.; Fulop, L.; Szucs, M.; Frecska, E. The Role of Sigma-1 Receptor, an Intracellular Chaperone in Neurodegenerative Diseases. Curr. Neuropharmacol. 2018, 16, 97-116. [CrossRef] 
140. Wang, D.; Zheng, M.; Lei, L.; Ji, J.; Yao, Y.; Qiu, Y.; Ma, L.; Lou, J.; Ouyang, C.; Zhang, X.; et al. Tespa1 is involved in late thymocyte development through the regulation of TCR-mediated signaling. Nat. Immunol. 2012, 13, 560-568. [CrossRef]

141. Li, Y.; Guo, Y.; Tang, J.; Jiang, J.; Chen, Z. New insights into the roles of CHOP-induced apoptosis in ER stress. Acta Biochim. Biophys. Sin. 2014, 46, 629-640. [CrossRef]

142. Hu, J.; Jin, J.; Qu, Y.; Liu, W.; Ma, Z.; Zhang, J.; Chen, F. ERO1alpha inhibits cell apoptosis and regulates steroidogenesis in mouse granulosa cells. Mol. Cell. Endocrinol. 2020, 511, 110842. [CrossRef]

143. Pozzer, D.; Varone, E.; Chernorudskiy, A.; Schiarea, S.; Missiroli, S.; Giorgi, C.; Pinton, P.; Canato, M.; Germinario, E.; Nogara, L.; et al. A maladaptive ER stress response triggers dysfunction in highly active muscles of mice with SELENON loss. Redox Biol. 2019, 20, 354-366. [CrossRef]

144. Laptenko, O.; Prives, C. p53: Master of life, death, and the epigenome. Genes Dev. 2017, 31, 955-956. [CrossRef]

145. Matsuo, Y.; Hirota, K. Transmembrane thioredoxin-related protein TMX1 is reversibly oxidized in response to protein accumulation in the endoplasmic reticulum. FEBS Open Bio 2017, 7, 1768-1777. [CrossRef] [PubMed]

146. Lewin, T.M.; Kim, J.H.; Granger, D.A.; Vance, J.E.; Coleman, R.A. Acyl-CoA synthetase isoforms 1, 4, and 5 are present in different subcellular membranes in rat liver and can be inhibited independently. J. Biol. Chem. 2001, 276, 24674-24679. [CrossRef] [PubMed]

147. Rusinol, A.E.; Cui, Z.; Chen, M.H.; Vance, J.E. A unique mitochondria-associated membrane fraction from rat liver has a high capacity for lipid synthesis and contains pre-Golgi secretory proteins including nascent lipoproteins. J. Biol. Chem. 1994, 269, 27494-27502. [CrossRef]

148. Simoes, I.C.M.; Morciano, G.; Lebiedzinska-Arciszewska, M.; Aguiari, G.; Pinton, P.; Potes, Y.; Wieckowski, M.R. The mystery of mitochondria-ER contact sites in physiology and pathology: A cancer perspective. Biochim. Biophys. Acta Mol. Basis Dis. 2020, 1866, 165834. [CrossRef] [PubMed]

149. Mullen, T.D.; Obeid, L.M. Ceramide and apoptosis: Exploring the enigmatic connections between sphingolipid metabolism and programmed cell death. Anticancer Agents Med. Chem. 2012, 12, 340-363. [CrossRef] [PubMed]

150. Chalfant, C.E.; Szulc, Z.; Roddy, P.; Bielawska, A.; Hannun, Y.A. The structural requirements for ceramide activation of serinethreonine protein phosphatases. J. Lipid Res. 2004, 45, 496-506. [CrossRef]

151. Lozano, J.; Berra, E.; Municio, M.M.; Diaz-Meco, M.T.; Dominguez, I.; Sanz, L.; Moscat, J. Protein kinase C zeta isoform is critical for kappa B-dependent promoter activation by sphingomyelinase. J. Biol. Chem. 1994, 269, 19200-19202. [CrossRef]

152. Zhang, Y.; Yao, B.; Delikat, S.; Bayoumy, S.; Lin, X.H.; Basu, S.; McGinley, M.; Chan-Hui, P.Y.; Lichenstein, H.; Kolesnick, R. Kinase suppressor of Ras is ceramide-activated protein kinase. Cell 1997, 89, 63-72. [CrossRef]

153. Saddoughi, S.A.; Ogretmen, B. Diverse functions of ceramide in cancer cell death and proliferation. Adv. Cancer Res. 2013, 117, 37-58. [CrossRef] [PubMed]

154. Huang, C.; Freter, C. Lipid metabolism, apoptosis and cancer therapy. Int. J. Mol. Sci. 2015, 16, 924-949. [CrossRef] [PubMed]

155. Stiban, J.; Caputo, L.; Colombini, M. Ceramide synthesis in the endoplasmic reticulum can permeabilize mitochondria to proapoptotic proteins. J. Lipid Res. 2008, 49, 625-634. [CrossRef] [PubMed]

156. Siskind, L.J.; Kolesnick, R.N.; Colombini, M. Ceramide channels increase the permeability of the mitochondrial outer membrane to small proteins. J. Biol. Chem. 2002, 277, 26796-26803. [CrossRef] [PubMed]

157. Coleman, R.A.; Lewin, T.M.; Van Horn, C.G.; Gonzalez-Baro, M.R. Do long-chain acyl-CoA synthetases regulate fatty acid entry into synthetic versus degradative pathways? J. Nutr. 2002, 132, 2123-2126. [CrossRef]

158. Lee, Y.J.; Jeong, S.Y.; Karbowski, M.; Smith, C.L.; Youle, R.J. Roles of the mammalian mitochondrial fission and fusion mediators Fis1, Drp1, and Opa1 in apoptosis. Mol. Biol. Cell 2004, 15, 5001-5011. [CrossRef] [PubMed]

159. Alirol, E.; James, D.; Huber, D.; Marchetto, A.; Vergani, L.; Martinou, J.C.; Scorrano, L. The mitochondrial fission protein hFis1 requires the endoplasmic reticulum gateway to induce apoptosis. Mol. Biol. Cell 2006, 17, 4593-4605. [CrossRef]

160. Yu, T.; Fox, R.J.; Burwell, L.S.; Yoon, Y. Regulation of mitochondrial fission and apoptosis by the mitochondrial outer membrane protein hFis1. J. Cell Sci. 2005, 118, 4141-4151. [CrossRef]

161. Arnoult, D.; Grodet, A.; Lee, Y.J.; Estaquier, J.; Blackstone, C. Release of OPA1 during apoptosis participates in the rapid and complete release of cytochrome $\mathrm{c}$ and subsequent mitochondrial fragmentation. J. Biol. Chem. 2005, 280, 35742-35750. [CrossRef]

162. Gao, W.; Pu, Y.; Luo, K.Q.; Chang, D.C. Temporal relationship between cytochrome c release and mitochondrial swelling during UV-induced apoptosis in living HeLa cells. J. Cell Sci. 2001, 114, 2855-2862. [PubMed]

163. Iwasawa, R.; Mahul-Mellier, A.L.; Datler, C.; Pazarentzos, E.; Grimm, S. Fis1 and Bap31 bridge the mitochondria-ER interface to establish a platform for apoptosis induction. EMBO J. 2011, 30, 556-568. [CrossRef] [PubMed]

164. Area-Gomez, E.; Schon, E.A. On the Pathogenesis of Alzheimer's Disease: The MAM Hypothesis. FASEB J. 2017, 31, 864-867. [CrossRef]

165. Wang, B.; Nguyen, M.; Chang, N.C.; Shore, G.C. Fis1, Bap31 and the kiss of death between mitochondria and endoplasmic reticulum. EMBO J. 2011, 30, 451-452. [CrossRef]

166. Sivaguru, M.; Urban, M.A.; Fried, G.; Wesseln, C.J.; Mander, L.; Punyasena, S.W. Comparative performance of airyscan and structured illumination superresolution microscopy in the study of the surface texture and 3D shape of pollen. Microsc. Res. Tech. 2018, 81, 101-114. [CrossRef]

167. Elgass, K.D.; Smith, E.A.; LeGros, M.A.; Larabell, C.A.; Ryan, M.T. Analysis of ER-mitochondria contacts using correlative fluorescence microscopy and soft X-ray tomography of mammalian cells. J. Cell Sci. 2015, 128, 2795-2804. [CrossRef] 
168. Csordas, G.; Weaver, D.; Hajnoczky, G. Endoplasmic Reticulum-Mitochondrial Contactology: Structure and Signaling Functions. Trends Cell Biol. 2018, 28, 523-540. [CrossRef]

169. Friedman, J.R.; Lackner, L.L.; West, M.; DiBenedetto, J.R.; Nunnari, J.; Voeltz, G.K. ER tubules mark sites of mitochondrial division. Science 2011, 334, 358-362. [CrossRef]

170. Murley, A.; Lackner, L.L.; Osman, C.; West, M.; Voeltz, G.K.; Walter, P.; Nunnari, J. ER-associated mitochondrial division links the distribution of mitochondria and mitochondrial DNA in yeast. eLife 2013, 2, e00422. [CrossRef] [PubMed]

171. Wu, Y.; Whiteus, C.; Xu, C.S.; Hayworth, K.J.; Weinberg, R.J.; Hess, H.F.; De Camilli, P. Contacts between the endoplasmic reticulum and other membranes in neurons. Proc. Natl. Acad. Sci. USA 2017, 114, E4859-E4867. [CrossRef]

172. Zhao, Y.G.; Chen, Y.; Miao, G.; Zhao, H.; Qu, W.; Li, D.; Wang, Z.; Liu, N.; Li, L.; Chen, S.; et al. The ER-Localized Transmembrane Protein EPG-3/VMP1 Regulates SERCA Activity to Control ER-Isolation Membrane Contacts for Autophagosome Formation. Mol. Cell 2017, 67, 974-989.e6. [CrossRef] [PubMed]

173. Williamson, C.D.; Wong, D.S.; Bozidis, P.; Zhang, A.; Colberg-Poley, A.M. Isolation of Endoplasmic Reticulum, Mitochondria, and Mitochondria-Associated Membrane and Detergent Resistant Membrane Fractions from Transfected Cells and from Human Cytomegalovirus-Infected Primary Fibroblasts. Curr. Protoc. Cell Biol. 2015, 68, 3.27.1-3.27.33. [CrossRef] [PubMed]

174. Cho, I.T.; Adelmant, G.; Lim, Y.; Marto, J.A.; Cho, G.; Golden, J.A. Ascorbate peroxidase proximity labeling coupled with biochemical fractionation identifies promoters of endoplasmic reticulum-mitochondrial contacts. J. Biol. Chem. 2017, 292, 16382-16392. [CrossRef] [PubMed]

175. Hung, V.; Lam, S.S.; Udeshi, N.D.; Svinkina, T.; Guzman, G.; Mootha, V.K.; Carr, S.A.; Ting, A.Y. Proteomic mapping of cytosol-facing outer mitochondrial and ER membranes in living human cells by proximity biotinylation. eLife 2017, 6. [CrossRef]

176. Herrera-Cruz, M.S.; Simmen, T. Over Six Decades of Discovery and Characterization of the Architecture at MitochondriaAssociated Membranes (MAMs). Adv. Exp. Med. Biol. 2017, 997, 13-31. [CrossRef] [PubMed]

177. Szymanski, J.; Janikiewicz, J.; Michalska, B.; Patalas-Krawczyk, P.; Perrone, M.; Ziolkowski, W.; Duszynski, J.; Pinton, P.; Dobrzyn, A.; Wieckowski, M.R. Interaction of Mitochondria with the Endoplasmic Reticulum and Plasma Membrane in Calcium Homeostasis, Lipid Trafficking and Mitochondrial Structure. Int. J. Mol. Sci. 2017, 18, 1576. [CrossRef] [PubMed] 